\title{
RMetS
}

Royal Meteorological Society

\section{Observation of convection initiation processes with a suite of state-of-the-art research instruments during COPS IOP 8b}

\author{
A. Behrendt, ${ }^{a \star}$ S. Pal, ${ }^{a}$ F. Aoshima, ${ }^{a}$ M. Bender, ${ }^{b}$ A. Blyth, ${ }^{c}$ U. Corsmeier, ${ }^{d}$ J. Cuesta, ${ }^{e}$ \\ G. Dick, ${ }^{b}$ M. Dorninger, ${ }^{\mathrm{f}}$ C. Flamant, ${ }^{\mathrm{g}}$ P. Di Girolamo, ${ }^{\mathrm{h}}$ T. Gorgas, ${ }^{\mathrm{f}}$ Y. Huang, ${ }^{\mathrm{c}}$ N. Kalthoff, ${ }^{\mathrm{d}}$ \\ S. Khodayar, ${ }^{\mathrm{d}}$ H. Mannstein, ${ }^{\mathrm{i}}$ K. Träumner, ${ }^{\mathrm{d}}$ A. Wieser ${ }^{\mathrm{d}}$ and V. Wulfmeyer ${ }^{\mathrm{a}}$ \\ ${ }^{a}$ Universität Hohenheim, Institut für Physik und Meteorologie, Stuttgart, Germany \\ ${ }^{\mathrm{b}}$ Helmholtz Centre Potsdam, German Research Centre for Geosciences, Germany \\ ${ }^{\mathrm{c}} \mathrm{NCAS}$, School of Earth and Environment, University of Leeds, UK \\ ${ }^{\mathrm{d}}$ Karlsruhe Institute of Technology (KIT), Germany \\ ${ }^{\mathrm{e}}$ Laboratoire de Meterologie Dynamique, CNRS and École Polytechnique, Palaiseau, France \\ ${ }^{\mathrm{f}}$ Department of Meteorology and Geophysics, University of Vienna, Austria \\ ${ }^{\mathrm{g}}$ Laboratoire Atmosphere, Milieux, Observations Spatiales, CNRS and Université Pierre et Marie Curie, Paris, France \\ ${ }^{\mathrm{h}}$ Dipartimento di Ingegneria e Fisica dell'Ambiente, Università degli Studi della Basilicata, Potenza, Italy \\ ${ }^{\mathrm{i}}$ Deutsches Zentrum für Luft- und Raumfahrt, Institute of Atmospheric Physics, Oberpfaffenhofen, Wessling, Germany \\ ${ }^{*}$ Correspondence to: Dr A. Behrendt, Universitat Hohenheim Institut fuer Physik und Meteorologie, Garbenstr. 30, \\ Stuttgart 70599, Germany. E-mail: andreas.behrendt@uni-hohenheim.de
}

In the afternoon of $15 \mathrm{July} 2007$, a thunderstorm was initiated within a line of cumulus clouds which formed parallel to the crest of the Black Forest mountains during the Intensive Observation Period (IOP) $8 \mathrm{~b}$ of the Convective and Orographicallyinduced Precipitation Study (COPS). This paper extends the analysis of processes that led to convection initiation (CI), i.e. the transition from shallow to deep convection, on this day with the data from several COPS instruments that have not been considered in previous studies. In particular, the boundary-layer structure, lids and the water-vapour field in the pre-convective environment of the event are discussed. For this purpose, we investigated measurements of water-vapour lidars, temperature lidars and wind lidars, profiles from radiosondes, in situ aircraft data and gridded data of weather stations as well as GPS integrated-water-vapour data and satellite imagery. Thermally driven circulation systems formed over both the Black Forest and the Vosges mountain ranges which resulted in local convergence zones. These superimposed with the large-scale convergence in the Black Forest area. In the presence of sufficient moisture and updraught, clouds formed close to the mountain crests. The related latent-heat release allowed larger thermals to be produced, which may have had a positive feedback on stabilizing these convergence zones as a whole. We believe that differences in the moisture field explain why convection remained shallow and sparse over the Vosges mountains because these differences were responsible for differences in convective inhibition (CIN). The stationary location of the convergence zone over the southern Black Forest was probably decisive for CI because it constantly transported sensible and latent heat into the area in which CI took place. Copyright (C) 2011 Royal Meteorological Society

Key Words: mountains; orography; remote sensing

Received 28 February 2010; Revised 25 November 2010; Accepted 30 November 2010; Published online in Wiley Online Library 9 February 2011

Citation: Behrendt A, Pal S, Aoshima F, Bender M, Blyth A, Corsmeier U, Cuesta J, Dick G, Dorninger M, Flamant C, Di Girolamo P, Gorgas T, Huang Y, Kalthoff N, Khodayar S, Mannstein H, Träumner K, Wieser A, Wulfmeyer V. 2011. Observation of convection initiation processes with a suite of state-of-the-art research instruments during COPS IOP 8b. Q. J. R. Meteorol. Soc. 137: 81-100. DOI:10.1002/qj.758 
Table I. Frequently used abbreviations.

\begin{tabular}{|c|c|}
\hline $\mathrm{ABL}$ & Atmospheric Boundary Layer \\
\hline AGL & Above Ground Level \\
\hline ASL & Above Sea Level \\
\hline BASIL & University of Basilicata Raman Lidar \\
\hline $\mathrm{BF}$ & Black Forest \\
\hline CAPE & Convective Available Potential Energy \\
\hline $\mathrm{CBL}$ & Convective Boundary Layer \\
\hline CI & Convection Initiation \\
\hline CIN & Convective Inhibition \\
\hline CNRS & $\begin{array}{l}\text { Centre National de la Recherche Scien- } \\
\text { tifique }\end{array}$ \\
\hline COPS & $\begin{array}{l}\text { Convective and Orographically-induced } \\
\text { Precipitation Study }\end{array}$ \\
\hline DIAL & Differential Absorption Lidar \\
\hline $\mathrm{DL}$ & Doppler Lidar \\
\hline DWD & $\begin{array}{l}\text { Deutscher Wetterdienst (German Weather } \\
\text { Service) }\end{array}$ \\
\hline GPS & Global Positioning System \\
\hline IOP & Intensive Observation Period \\
\hline IWV & Integrated Water Vapour \\
\hline KIT & Karlsruhe Institute of Technology \\
\hline MFC & Moisture Flux Convergence \\
\hline MFD & Moisture Flux Divergence \\
\hline ML & Moist Layer \\
\hline MSG & $\begin{array}{l}\text { Meteosat Second Generation } 1= \\
\text { Meteosat- } 8\end{array}$ \\
\hline LCL & Lifting Condensation Level \\
\hline LEANDRE II & $\begin{array}{l}\text { Lidar Embarqué pour l'étude des Aérosols, } \\
\text { des Nuages, de l'interaction Dynamique } \\
\text { Rayonnement et du cycle de l'Eau } \\
\text { airborne water-vapour DIAL of CNRS }\end{array}$ \\
\hline PRINCE & $\begin{array}{l}\text { Prediction, Identification and Tracking of } \\
\text { Convective Cells = field campaign in } 2006 \\
\text { in the Black Forest }\end{array}$ \\
\hline $\mathrm{UHOH}$ & University of Hohenheim \\
\hline UTC & Universal Time Coordinated \\
\hline VERA & Vienna Enhanced Resolution Analysis \\
\hline WVMR & Water-Vapour Mixing Ratio \\
\hline
\end{tabular}

\section{Introduction}

Errors in the location and time of convective precipitation are among the most critical issues in the effort to forecast precipitation quantitatively with numerical weather forecast models (e.g. Carbone et al., 2002; Ebert et al., 2003; Fritsch and Carbone, 2004; Richard et al., 2007; Schwitalla et al., 2008). As a consequence, a number of field campaigns have been carried out in recent years to investigate the atmospheric processes related to convection initiation (CI; see Table I for a list of all frequently used abbreviations) in order to improve their model representation, e.g. IHOP_2002, the International $\mathrm{H}_{2} \mathrm{O}$ Project in 2002 (Weckwerth et al., 2004; Weckwerth and Parsons, 2006), the Convective Storm Initiation Project (CSIP) in 2005 (Browning et al., 2007), and the Prediction, Identification and Tracking of Convective Cells campaign 'PRINCE' in 2006 (e.g. Groenemeijer et al., 2008).
Quantitative precipitation forecasting in mountainous areas is of particular importance because depending on which river catchments are affected, convective systems may or may not lead to severe flooding events (Rotach et al., 2009a, 2009b). The field phase of the Convective and Orographically-induced Precipitation Study (COPS) was performed in the summer of 2007 and was the first Research and Development Project of the World Weather Research Programme related to convective precipitation in a low-mountain region (Wulfmeyer et al., 2008, 2011). The so-called COPS mesoscale target region ('COPS region' in the following) was set up in Central Europe covering the French Vosges mountains, the Rhine Valley, and the Black Forest mountains in Germany (Figure 1).

While convective available potential energy (CAPE) is a prerequisite for deep convection, the exact location and time of CI, i.e. when and where convective inhibition (CIN) is overcome and consequently the transition between shallow non-precipitating convection and precipitating deep convection takes place, depend critically on the presence and strength of wind convergence and the amount of moisture in the source layer as well as the ambient atmosphere in the pre-convective environment. The variation in the depth of the atmospheric boundary layer $(\mathrm{ABL})$ is also key to understanding the reasons for CI because the height of the ABL plays an important role in the accumulation and distribution of moisture.

The variability of the ABL height over complex terrain was the topic of a number of previous studies. For instance, Lenschow et al. (1979) observed a highly inhomogeneous $\mathrm{ABL}$ structure in complex terrain in the early morning, but the afternoon ABL structure tended to be horizontally more homogeneous. Dayan et al. (1988) concluded that orography is a major factor determining the ABL height variability in complex terrain, rather than differences in synoptic conditions or land use. In the Black Forest region, for example, De Wekker et al. (1997), Kossmann et al. (1998) and Kalthoff et al. (1998) discussed observations of the ABL structure. ABL heights in all these studies were determined primarily from vertical temperature profiles obtained with radiosoundings during different times of the day and aircraft observations, both of which have only limited spatial and temporal coverage. In recent years, the development of remote-sensing systems has provided improved data coverage for the investigation of $\mathrm{ABL}$ characteristics. Due to the higher spatial and temporal resolutions of remote-sensing measurements, possible sampling errors of radiosondes are avoided (Weckwerth et al., 1996; Whiteman et al., 2006). Particularly, continuous monitoring of the ABL height with upward-looking or scanning ground-based lidar or downward-looking airborne lidar have proven to be very useful for the investigation of both temporal and spatial variability of ABL heights (Wulfmeyer and Feingold, 2000; Pal et al., 2010; Bennett et al., 2011). Lidar measurements of the ABL structure from Hornisgrinde (COPS supersite $\mathrm{H}$ ) were made during the campaign PRINCE (see above) one year before COPS (Groenemeijer et al., 2008; Radlach et al., 2008).

In this study, we investigate CI on 15 July 2007 (COPS IOP $8 b$ ). On this day a thunderstorm developed in the early afternoon above the Black Forest. The initiation of convection in this case was an example of locally initiated convection (Kottmeier et al., 2008), also called air-mass convection (Wulfmeyer et al., 2011). The other major type 

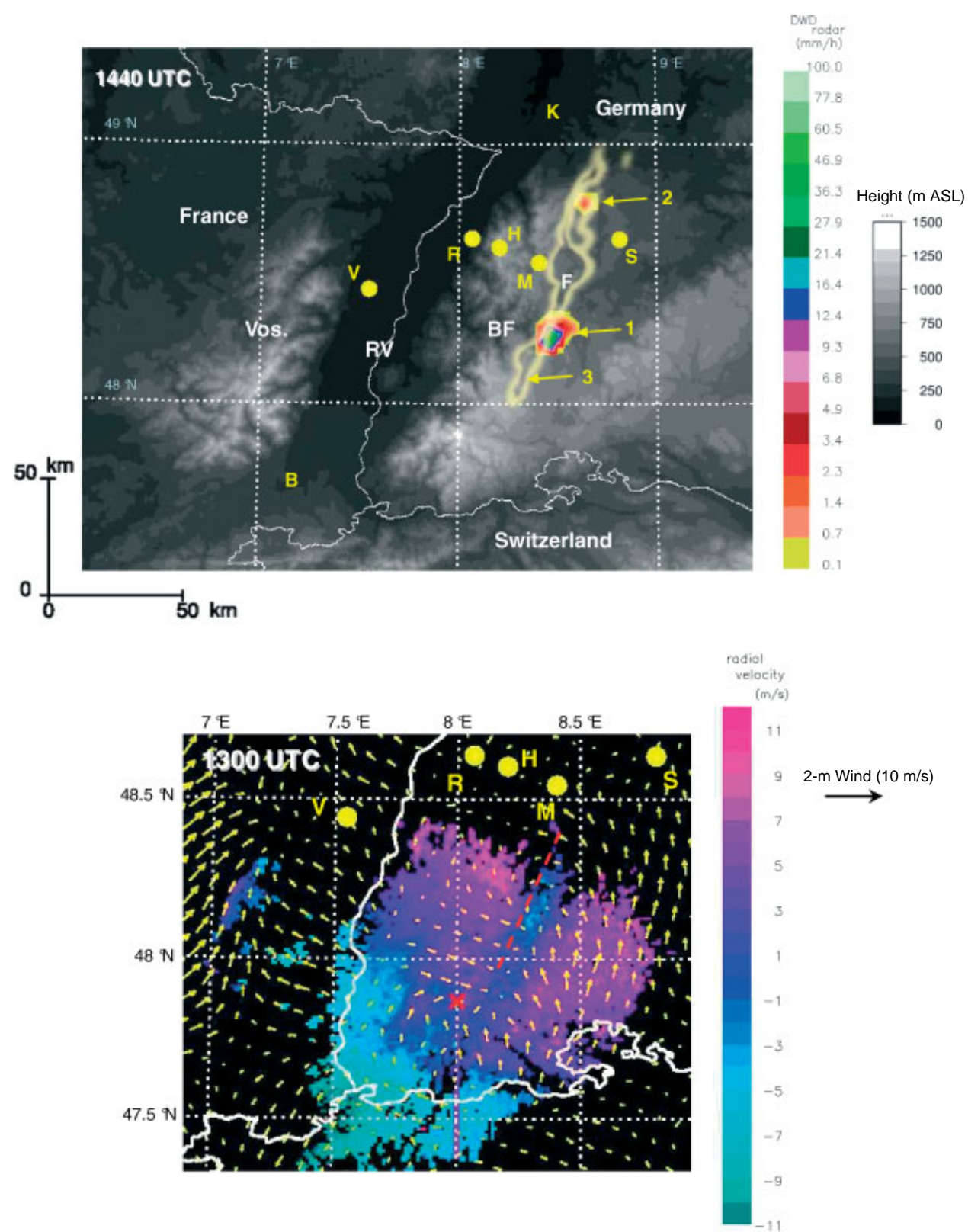

Figure 1. Upper panel: Orography of the COPS region (grey-scale background), DWD radar composite (colour contours), and cloud boundaries seen with MSG (bright-yellow contours) at 1440 UTC on 15 July 2007. Two precipitating cells are present in the central and northern Black Forest. A third cell appeared at 1450 UTC (yellow arrows with cell numbers). COPS supersites V, R, H, M, and S are marked with yellow circles. COPS radiosonde sites $\mathrm{B}$ and $\mathrm{K}$, and the ceilometers site in Freundenstadt (F) are marked with yellow letters. Vos.: Vosges mountains, BF: Black Forest mountains, RV: Rhine Valley. Lower panel: Radial velocity (in colour) measured with the DWD radar within a horizontal scan from Feldberg mountain (red cross), the highest mountain of the Black Forest, with wind at $10 \mathrm{~m} \mathrm{AGL}$ at 1300 UTC (gridded observations of VERA with $2 \mathrm{~km}$ resolution). Negative values of radial velocity show flow towards the radar, positive values away from the radar. A convergence zone is clearly visible in the radial radar data (red dashed line). The location of this zone coincides with the presence of clouds (not shown here).

of convection in the region, convection near frontal zones, is discussed by e.g. Corsmeier et al. (2011).

Aoshima et al. (2008) analysed CI on all COPS IOPs with rapid-scanning data of Meteosat-8 (also called Meteosat Second Generation 1, MSG) and showed satellite images with 5 -minute resolution of IOP $8 \mathrm{~b}$ to illustrate their approach. The authors found no preferred area for CI within the COPS region. It can be concluded that it is essential to understand the different forcing mechanisms of each case in order to reveal the case-dependent causes for CI in this region.

Kalthoff et al. (2009) studied a subset of COPS data of IOP $8 \mathrm{~b}$ and proposed that west-to-east moving convergence zones were present on this day over the Black Forest mountains. The spatial and temporal variability of moisture and its relation to $\mathrm{CI}$ in this case was not investigated. Barthlott et al. (2010) used the convection-resolving model COSMO-DE of the German Weather Service (DWD) with 2.8 and $1.0 \mathrm{~km}$ grid spacing to simulate the mechanisms which led to CI during IOP $8 \mathrm{~b}$. The model developed a convergence line and the evolution of a line of low clouds above the Black Forest in good agreement with radar and satellite observations but, despite a moderate amount of CAPE and almost vanishing CIN, no precipitating deep convection developed from this line of clouds in the model. In contrast to COSMO-DE, the MESO-NH model was successful in simulating convective precipitation in this case (Richard et al., 2011). A comparison study of modelling 
results for IOP $8 \mathrm{~b}$ with a suite of convection-resolving models was discussed by Barthlott et al. (2011). An idealized simulation of this case with even higher cloud-resolving resolution (minimum horizontal grid spacing of $100 \mathrm{~m}$ ) was discussed by Kirshbaum (2011) who showed that the existence and vigour of the convection is highly sensitive to small changes in the background wind speed.

This article extends the analysis of processes that led to CI during COPS IOP $8 \mathrm{~b}$ with the data of several COPS instruments which have not been considered in previous studies of this case. In particular, water-vapour measurements have been included in the analysis because small differences in moisture can be crucial for predicting CI correctly (e.g. Crook, 1996; Weckwerth, 2000; Fabry, 2006). Especially, the suite of ground-based and airborne watervapour lidars employed during COPS is an excellent tool for this purpose because the data show both high temporal and spatial resolution and high accuracy (Bhawar et al., 2011). In order to study the relation of different observations with each other, composite images of several datasets were made.

The article is organised as follows: Section 2 gives an overview of the meteorological conditions on 15 July 2007 in the COPS region. In section 3, we introduce briefly the instrumentation and data analysis techniques. In section 4, we present the most salient results obtained with the analyses. Finally, conclusions are drawn in section 5 .

\section{Meteorological conditions, clouds and observed precipitation on 15 July 2007}

Kottmeier et al. (2008) have already discussed the synoptic weather conditions of IOP $8 \mathrm{~b}$, and further details have been given by Aoshima et al. (2008), Kalthoff et al. (2009) and Barthlott et al. (2010). Thus, we restrict ourselves to a brief overview here.

On 15 July, the synoptic situation was dominated by the presence of a deep eastern Atlantic trough and a ridge extending from the Mediterranean to Poland. In the low levels, the COPS region was under the influence of a strong south-westerly flow while east of the COPS region south-easterly winds were present. Data analyses of the ground-based ceilometer network and satellite observations together with visual observations during the field phase report no clouds in the COPS region in the morning. This cloud-free situation allowed for high insolation of the COPS region and the consequent development of thermal flow systems, i.e. so-called mountain-valley wind systems. Between 1100 and 1200 UTC cumulus clouds formed above the ridges of the Vosges and Black Forest mountains. The clouds over the Vosges stayed shallow and sparse while above the Black Forest a line of towering cumulus clouds formed in the early afternoon. This line extended from the northern to the southern Black Forest for about $100 \mathrm{~km}$ parallel to the Black Forest ridge with a shift of about $20 \mathrm{~km}$ to the east. The minimum brightness temperature at $10.8 \mu \mathrm{m}$ in the COPS region measured by Meteosat- 8 decreased continuously from $300 \mathrm{~K}$ at $1145 \mathrm{UTC}$ to $270 \mathrm{~K}$ at 1400 UTC (Aoshima et al., 2008), indicating continuous increase of cloud-top heights and cloud fraction within the satellite pixels. The DWD Feldberg radar, which is located near the summit of the southern Black Forest with an unobstructed view over the Black Forest, detected a convergence line below the cloud band (Figure 1).
As discussed by Wilson and Schreiber (1986), such lines favour CI. Indeed, three separate precipitation cells appeared later at the line of clouds (labelled 1, 2 and 3 in Figure 1). Precipitation of the first and largest cell was detected by the DWD Feldberg radar from 1420 to 1525 UTC with maximum radar reflectivity of $\sim 55 \mathrm{dBZ}$ between 1440 and 1445 UTC. The second cell was present from 1430 to 1455 UTC with maximum reflectivity of $\sim 30 \mathrm{dBZ}$ at 1440 UTC; the third from 1450 to 1550 UTC with $\sim 40 \mathrm{dBZ}$ at 1520 UTC. Aoshima et al. (2008) showed photographs of the large thunderstorm of this day (cell 1) taken from the COPS supersite $\mathrm{H}$ at Hornisgrinde, the highest peak in the northern Black Forest. Their analysis of brightness temperature data at $10.8 \mu \mathrm{m}$ of Meteosat- 8 reveals a minimum temperature change rate at the top of this cloud of $-4.0 \mathrm{~K} / \mathrm{min}$ between 1430 and 1435 UTC corresponding to a rapid increase in height. A $10.8 \mu \mathrm{m}$ brightness temperature of less than $250 \mathrm{~K}$ is reached by this cell at 1430 UTC. The authors define this temperature as a threshold for CI. It should be noted that the definition of CI is not uniform in the literature; this definition identifies a mature state of deep convection at which precipitation typically has already reached the ground. The threshold brightness temperature of $250 \mathrm{~K}$ was not reached by the other smaller precipitation cells over the COPS region on this day. It is interesting to note that the temperature change rate found with the 5-minute satellite data is twice the value compared to $-2.0 \mathrm{~K} /$ minute which is found if only 15-minute data are analysed. These are much larger values than the ones reported by Roberts and Rutledge (2003). They found temperature change rates of up to $-1 \mathrm{~K} /$ minute but for the median of a certain area and with a temporal resolution of the satellite data of 15 minutes.

\section{Instrumentation and analysis tools}

In the following, we provide a brief introduction to the instruments and techniques that are used in this study. A detailed overview of the complete set-up of the instruments during the whole COPS period can be found in the COPS Field Report (Wulfmeyer and Behrendt, 2007).

\subsection{Soundings with lidar, aircraft and radiosondes}

Most ground-based remote-sensing instruments of COPS were collocated at five supersite observatories in order to allow for measurement synergies. The supersites were located along a west-east transect through the COPS region: at the eastern edge of the Vosges (supersite V, $157 \mathrm{~m}$ above sea level (ASL)), in the Rhine Valley (R, $140 \mathrm{~m} \mathrm{ASL}$ ), at Hornisgrinde peak ( $\mathrm{H}, 1150 \mathrm{~m} \mathrm{ASL})$, in the Murg valley (M, $541 \mathrm{~m} \mathrm{ASL})$ in the northern Black Forest, and close to Sindelfinden (S, $600 \mathrm{~m}$ ASL) (Figure 1). The central supersites $\mathrm{R}, \mathrm{H}$ and $\mathrm{M}$ were on one line with distances of $10.7 \mathrm{~km}$ from $\mathrm{R}$ to $\mathrm{H}$ and $16.1 \mathrm{~km}$ from $\mathrm{H}$ to $\mathrm{M}$, respectively.

Two ground-based lidars provided water-vapour profiles in the daytime during COPS: the water-vapour differentialabsorption lidar of the University of Hohenheim (UHOH DIAL: Behrendt et al., 2009) and the University of Basilicata Raman lidar (BASIL: Di Girolamo et al., 2004, 2009) at the supersites $H$ and $R$, respectively. Temporal and spatial resolution in the water-vapour profiles of the UHOH DIAL which is based on advanced laser technology (see e.g. Wulfmeyer and Boesenberg, 1996) are $10 \mathrm{~s}$ and $15 \mathrm{~m}$, respectively, with each data point having a triangular 
weighting function with a length of $150 \mathrm{~m}$. Temporal and spatial resolutions of BASIL water-vapour data in daytime are 5 minutes and $300 \mathrm{~m}$, respectively.

Daytime temperature profiles of the rotational Raman lidar of the University of Hohenheim (Radlach et al., 2008), also located at supersite $\mathrm{H}$, are used to study temperature lids. Vertical velocity measurements were made with the Doppler lidar (DL) of Karlsruhe Institute of Technology (KIT) at supersite H. A correlation of the UHOH DIAL and KIT DL yields latent heat flux. The lidars at the other supersites, unfortunately, did not provide daytime measurements of moisture. Thus, we used the elastic backscatter data of the aerosol lidar of Centre Nationale de la Recherche Scientific (CNRS) at supersite $\mathrm{V}$ and micropulse lidar of the ARM (Atmospheric Radiation Measurement) Mobile Facility at supersite $\mathrm{M}$ in this study to look at aerosols as tracers for the $\mathrm{ABL}$ and at clouds.

Two research aircraft were equipped with lidars: the Falcon of DLR (Deutsches Zentrum für Luft- und Raumfahrt) and the Falcon of SAFIRE (Service des Avions Français Instrumentés pour la Recherche en Environnement). The DLR Falcon flew only in the morning (0625 to 0855 UTC) in the COPS region and collected water-vapour data for about one hour between 0640 and 0733 UTC. The SAFIRE Falcon with the water-vapour DIAL LEANDRE II (Bruneau et al., 2001) was operated on this day for more than 6.5 hours in the COPS region, 0634 to 0957 UTC in the morning and 1141 to 1455 UTC in the early afternoon. LEANDRE II performed the two missions along a grid-type pattern at an altitude of $5000 \mathrm{~m}$ ASL so that vertical cross-sections of water-vapour mixing ratio (WVMR) profiles from this height down to about $500 \mathrm{~m}$ above ground were measured. The vertical resolution of the data is $300 \mathrm{~m}$ and the temporal resolution is $5 \mathrm{~s}$ which corresponds to a horizontal distance of just $875 \mathrm{~m}$ between independent profiles.

Detailed intercomparisons of the measurements of the different lidar systems during aircraft overpasses were performed by Bhawar et al. (2011) with the COPS dataset, similar to those done by Behrendt et al. (2007a, 2007b) for IHOP_2002. They found that the water-vapour measurements of LEANDRE II, UHOH DIAL and BASIL agree very well. The mean relative differences of these three instruments were only $1.7,-1.4$ and $0.4 \%$, respectively, which makes them the instruments of choice for studying atmospheric moisture fields.

The research aircraft Do-128 operated by the University of Braunschweig and KIT (Corsmeier et al., 2001) and the BAe146 aircraft of FAAM (Facility for Airborne Atmospheric Measurements) performed meteorological measurements at different height levels over the COPS region on this day. In addition, 28 radiosondes were launched between 0500 and 1730 UTC from the supersites and two more COPS stations at the northern and southern borders of the COPS region.

\subsection{Gridded surface observations}

Several networks of surface weather stations were operated continuously in the COPS region by different agencies. Additional weather stations were set up especially for COPS in order to close gaps at particularly interesting locations (see Wulfmeyer et al. (2011) for details). The combination of surface-station networks results in about 150 stations giving hourly data of temperature, moisture and wind near the surface in the COPS region (the exact number of stations changes from time to time for each parameter). We used the VERA system (Vienna Enhanced Resolution Analysis: Steinacker et al., 2000) to generate gridded surface datasets with a horizontal resolution of $2 \mathrm{~km}$ and a temporal resolution of 1 hour by spatial interpolation of these irregularly distributed measurements; higher temporal analyses would result in too-low data density due to the temporal resolution of weather station data available. VERA combines a quality control scheme (Häberli et al., 2004) with a sophisticated interpolation algorithm using the so-called fingerprint method (Steinacker et al., 2006).

A key feature of VERA is that no first guess is necessary to run the analysis. The system calculates gridded fields of several meteorological parameters, including potential temperature, equivalent potential temperature, mean-sealevel pressure, horizontal wind and precipitation. From these fields, we derived further parameters for this study, such as WVMR, two-dimensional moisture flux divergence (MFD: Kaufmann, 2006) and lifting condensation level (LCL). In the past the estimation of the moisture flux convergence MFC (= negative MFD) has been widely used for estimating CI in the literature (e.g. Hudson, 1971; Doswell, 1977). Banacos and Schultz (2005) pointed out that, for smaller mesoscale phenomena, MFC is governed by the convergence part and hence is closely related to the mass convergence. Low-level mass convergence can therefore be used as an indicator for CI as well. In our analysis we stick to MFC as the original term appearing in the water-vapour budget equation and calculated by numerical weather prediction models. We have used the MFD analysis of VERA to investigate whether favourable spatial locations for CI can be determined with the near-surface data in this case. The VERA topography can be interpreted as a strongly smoothed surface following the lowlands and valleys (Bica et al., 2007). Evaluating the moisture flux along this topography we achieve a qualitative estimation of its true value.

\subsection{GPS-derived integrated water vapour}

The existing French and German global positioning system (GPS) networks were densified in the COPS region in order to provide integrated water vapour (IWV) observations with a high spatial and temporal resolution (Crewell et al., 2008). The data of about 190 stations were analysed in near real-time by the German Research Centre for Geosciences (GFZ) in summer 2007. After collecting the data of GPS stations which were operated off-line and getting access to observations from other GPS providers not related to COPS, the total number of stations could be increased to more than 370 whereof 48 are located in the COPS region. These data were reprocessed by the GFZ using the GPS processing software EPOS (Gendt et al., 2004). To derive IWV, further surface meteorological observations are required (Dick et al., 2001). These observations are not available for all GPS stations, so IWV observations are available for 39 stations in the COPS region. For this study, the IWV station observations were interpolated onto a regular grid with a horizontal resolution of $2.8 \mathrm{~km}$. Unfortunately, no IWV observations south of $48^{\circ} 20^{\prime}$ were available for IOP $8 \mathrm{~b}$. The IWV isolines were therefore extrapolated and can only be used as an estimate of the IWV distribution at lower latitudes. 


\subsection{Fields of CIN and CAPE}

To support the investigation of CI on this day, the spatio-temporal distribution of CAPE and CIN in the COPS region has been analysed using VERA surface meteorological parameters, GPS-IWV measurements and combined radiosonde profiles. In order to be able to combine these datasets and produce the necessary input fields of temperature and moisture in the ambient atmosphere and near the ground, the method introduced by Khodayar et al. (2010) was applied. First, the input fields of all datasets were interpolated onto a regular $11 \mathrm{~km}$ grid. The interpolated temperature and moisture profiles obtained by the combination of datasets were then used to calculate the ambient curves. The corresponding lifting curve for each grid point was calculated with a mixed-layer parcel average over the lowest $50 \mathrm{hPa}$ of each profile taking the height of each station into account (Craven et al., 2002).

\subsection{Composite plots including satellite images and radar data}

Overlay plots of the orography in the region with clouds detected with the high-resolution channel of the geostationary-satellite images, precipitation rates measured by radar, VERA fields, lidar, GPS-IWV and aircraft measurements were made for this study to investigate the relation and interaction of dynamic and thermodynamic processes.

The European Organisation for the Exploitation of Meteorological Satellites (EUMETSAT) provided reduced scans with the geostationary satellite Meteosat- 8 during COPS which yielded high-resolution images with the instrument SEVERI (Spinning Enhanced Visible and Infrared Imager) every 5 minutes instead of the operational 15 minutes at that time (Aoshima et al., 2008). The highresolution visible (HRV) channel provided images with $1 \mathrm{~km}$ rezel sampling interval at the sub-satellite point which corresponds to $1.9 \mathrm{~km}$ and $1.1 \mathrm{~km}$ rezel side lengths over central Europe in the north-south and west-east directions, respectively. It should be noted that the apparent location of high clouds is slightly shifted by the parallax effect to the north and east compared to the ground-surface location in these images because Meteosat- 8 is in a geostationary orbit at about $36000 \mathrm{~km}$ above the Equator. The parallax effect depends on the cloud height: When the cloud-top heights are $6 \mathrm{~km}, 8 \mathrm{~km}$ and $10 \mathrm{~km}$, the differences between the ground site and the location identified by Meteosat8 are $8.7 \mathrm{~km}, 11.7 \mathrm{~km}$ and $14.6 \mathrm{~km}$ respectively, at the centre of the COPS region $\left(8^{\circ} \mathrm{E}, 48.5^{\circ} \mathrm{N}\right)$. The German radar precipitation composites are available with spatial and temporal resolutions of $2.8 \mathrm{~km}$ and 5 minutes.

\section{Observations during IOP $8 b$}

\subsection{CAPE and CIN}

Kottmeier et al. (2008), Kalthoff et al. (2009) and Barthlott et al. (2010) have discussed convective indices on 15 July 2007 on the basis of some radiosoundings (namely from the sites $\mathrm{K}, \mathrm{B}, \mathrm{R}$ and $\mathrm{M}$ ) made in the COPS area. Therefore, their analyses are limited to these areas and times for which radiosoundings are available. The investigation resulted in only moderate values of CAPE (maximum of $1201 \mathrm{~J} / \mathrm{kg}$ at K at 1700 UTC) and relatively high values of CIN (minimum of $78 \mathrm{~J} / \mathrm{kg}$ at $\mathrm{M}$ at $1129 \mathrm{UTC}$ ). One should be careful not to overinterpret CAPE and CIN analyses because they are based on a simple parcel analysis which neglects, e.g., the influence of entrainment, weighting of the cloud particles and the latent heat release due to freezing. Nevertheless, the analyses of the radiosonde ascents showed that deep convection was unlikely. However, initiation of convection did occur in the region. To understand this discrepancy, a higher-resolution analysis with $11 \mathrm{~km}$ grid resolution of the distribution of the convective indices in the area of interest was performed with the technique described in section 3.4.

Interpolated fields of CAPE and CIN for 1100 and 1400 UTC are shown in Figure 2. The CAPE and CIN fields at 1100 UTC exhibit relatively low CAPE values in most of the area, of between 0 and $200 \mathrm{~J} / \mathrm{kg}$, and high CIN values of between 100 and $350 \mathrm{~J} / \mathrm{kg}$, except for an elongated region where higher values of CAPE, 600 to $1700 \mathrm{~J} / \mathrm{kg}$, and lower values of CIN, 30 to $100 \mathrm{~J} / \mathrm{kg}$, are found. The regions of maximum CAPE and minimum CIN approximately coincide with the ridge of the northern Black Forest that lies about $15 \mathrm{~km}$ west of the area where the formation of the first convective clouds was observed. Three hours later, at about 1400 UTC, the CAPE values have increased at all points of the area. The region of maximum CAPE with values above $2500 \mathrm{~J} / \mathrm{kg}$ is located in the northeastern part of the analysed region. The CIN field at 1400 UTC shows in the whole area lower values than at 1100 UTC. The CIN values are mostly above $100 \mathrm{~J} / \mathrm{kg}$ but with the exception of a region close to Hornisgrinde where CIN is even below $10 \mathrm{~J} / \mathrm{kg}$.

In summary, we can state that high values of CAPE are available over the Black Forest and thus this prerequisite of deep convection is given; furthermore, CIN is moderate. Regions of maximum CAPE or minimum CIN do not coincide with the location of CI (which is not surprising because CAPE and CIN describe only the preconditioning of the atmosphere for CI).

\subsection{Distribution of moisture}

The distributions of CIN and CAPE on this day are highly related to the spatial distribution and temporal evolution of boundary-layer water vapour in the area. The VERA fields (see section 3.2) of WVMR at $2 \mathrm{~m} \mathrm{AGL}$ are shown in Figure 3 together with the VERA horizontal wind at $10 \mathrm{~m}$ AGL, clouds observed with MSG, and radar precipitation.

Figure 3, upper panel, shows high humidity at the western slope of the Black Forest at 1100 UTC. WVMRs of more than $18 \mathrm{~g} / \mathrm{kg}$ were present in the northern Rhine Valley while much lower values of less than $12 \mathrm{~g} / \mathrm{kg}$ are found at the Vosges and Black Forest mountains. At 1400 UTC, the surface moisture distribution showed a similar structure to 1100 UTC but the near-surface humidity at 1400 UTC had generally decreased compared to 1100 UTC, which is consistent with the development of a convective boundary layer and with entrainment of drier air at the top of this layer.

Figure 4 shows the GPS-IWV field at 900, 1200 and 1400 UTC. Minima with GPS-IWV $<20 \mathrm{~kg} / \mathrm{m}^{2}$ are found west of the Vosges and in the southeastern part of the analysed region. A region with maximum GPS-IWV was present north of the northern Black Forest, with values larger than $30 \mathrm{~kg} / \mathrm{m}^{2}$ even though no clouds were present here. Thus, it can be stated that the general structure of the water-vapour 


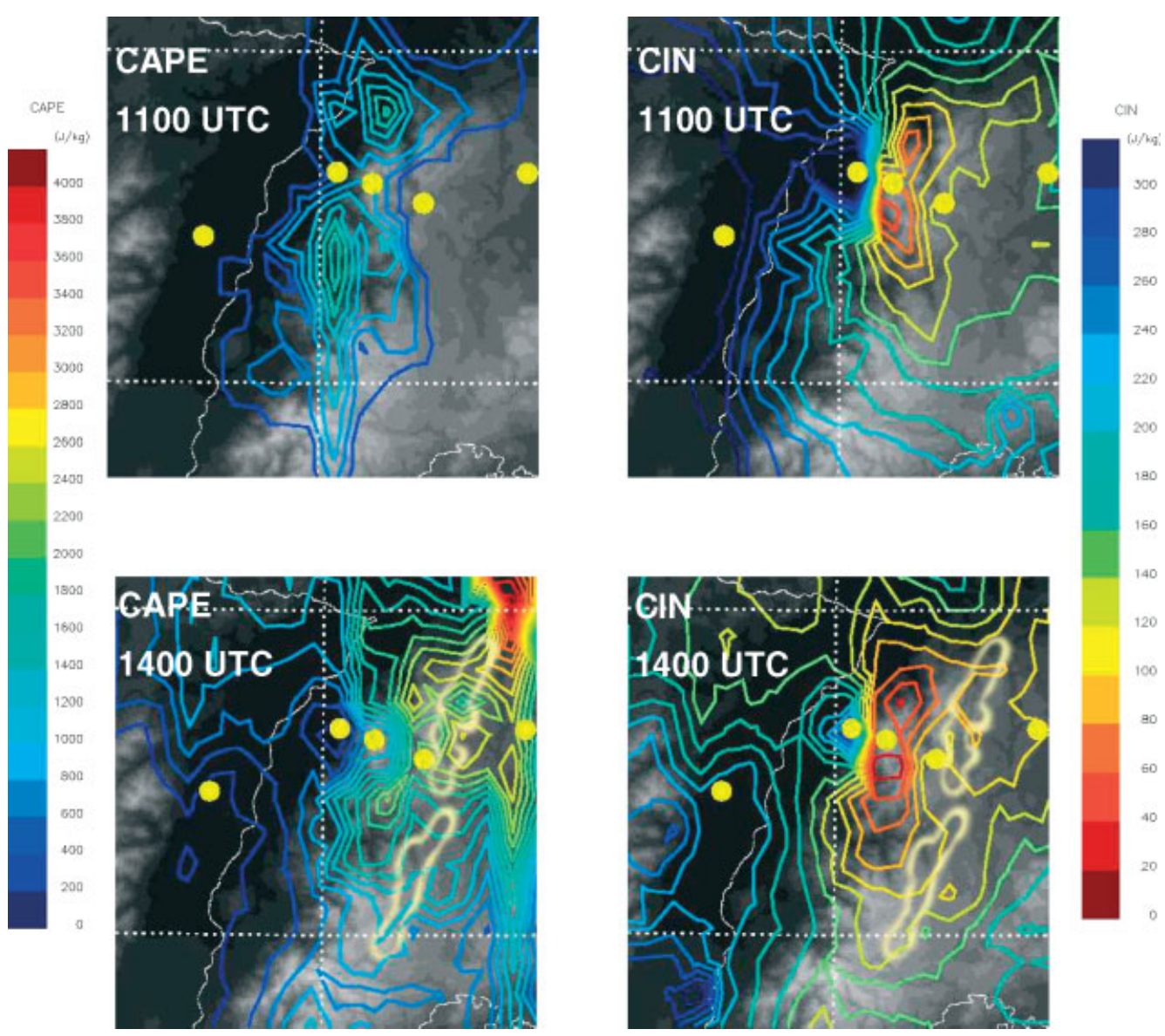

Figure 2. Upper panels: Fields of CAPE (left) and CIN (right) at 1100 UTC with $11 \mathrm{~km}$ grid resolution (see text for details). Lower panels: same as upper panels but for 1400 UTC. Bright yellow contours show clouds; the orography in the background has the same scale as in Figure 1.

field near the surface (VERA data in Figure 3) was also present in the columnar water vapour.

Looking into details of GPS-IWV at 1200 UTC, the transect of stations from the northern Vosges over the Rhine Valley to the northern Black Forest shows significantly larger values over the mountains than over the Rhine Valley (19 kg/m $\mathrm{m}^{2}$ compared to $>25 \mathrm{~kg} / \mathrm{m}^{2}$ ) which corresponds to transport of moisture from the Rhine Valley to the adjacent mountains by thermal flows. Near the region of clouds in the eastern Black Forest, where precipitation was initiated, the GPS-IWV field did not show any significant enhancement before clouds formed (IWV was around $23 \mathrm{~kg} / \mathrm{m}^{2}$ here at 1200 UTC). Only at 1400 UTC did the station at supersite M show $29 \mathrm{~kg} / \mathrm{m}^{2}$, which is consistent with the location of this site just below the convergence zone with its towering cumulus clouds.

If the water-vapour field in the free troposphere was homogeneous, differences in GPS-IWV could be attributed to differences in boundary-layer moisture alone, i.e. different mixing ratio values, if the $\mathrm{ABL}$ height is the same, or different $\mathrm{ABL}$ heights, if the mixing ratio is constant within the ABL. The water-vapour profiles determined by lidar, however, reveal that the water-vapour mixing ratio varied significantly also above the boundary layer in this case so that the contributions to the IWV field were diverse.

Figure 5 shows measurements performed by LEANDRE II along representative legs of this day. Nearly the whole atmosphere along the flight track in the morning as well as in the afternoon was cloud free. The measurements of LEANDRE II show the extension of a moist layer (ML) close to the ground and its spatial and temporal variability. Here, the ML height was obtained from the Haar-wavelet analyses (Pal et al., 2010) of the WVMR profiles. The maximum of the wavelet analysis was labelled as the top of the ML. Because a residual ML was present in the morning of IOP $8 \mathrm{~b}$, the ML top heights do not necessarily agree with the top heights of the convective boundary layer $(\mathrm{CBL})$ which is defined as the height at which the variance of moisture (and other tracers) has its maximum.

Different characteristics of the ML height within the COPS region are found in these data. In the morning flight (Figure 4, upper panel), when thermal convection was still weak, the ML heights were more evenly distributed in the region and differences between the Rhine Valley and the adjacent mountains were less pronounced. However, an increase with increasing elevation can be seen (e.g. on legs L7 and L8, Figure 5(c) and (d)) although the differences in ML height were not as large as the differences in surface elevation. Within the course of the day as there was a change from an ML characterised by residual air masses to an ML characterised by thermal convection, the ML height became more and more terrain-following (Figure 4, middle and bottom panel; L13 of Figure 5(f)).

The first leg $\mathrm{L} 1$ of LEANDRE II passed the supersites $\mathrm{H}$ and $\mathrm{R}$ on an east-west transect at about 0640 UTC (Figure 5(a)). Both L1 as well as the parallel leg L2 (not shown) demonstrate already at this time values of the WVMR of up to $12 \mathrm{~g} / \mathrm{kg}$ at about $1600 \mathrm{~m}$ ASL in the Rhine Valley. Above the ML, a second elevated humid layer with 6 to $7 \mathrm{~g} / \mathrm{kg}$ at $3000 \mathrm{~m}$ ASL was observed. The height of this elevated layer was 


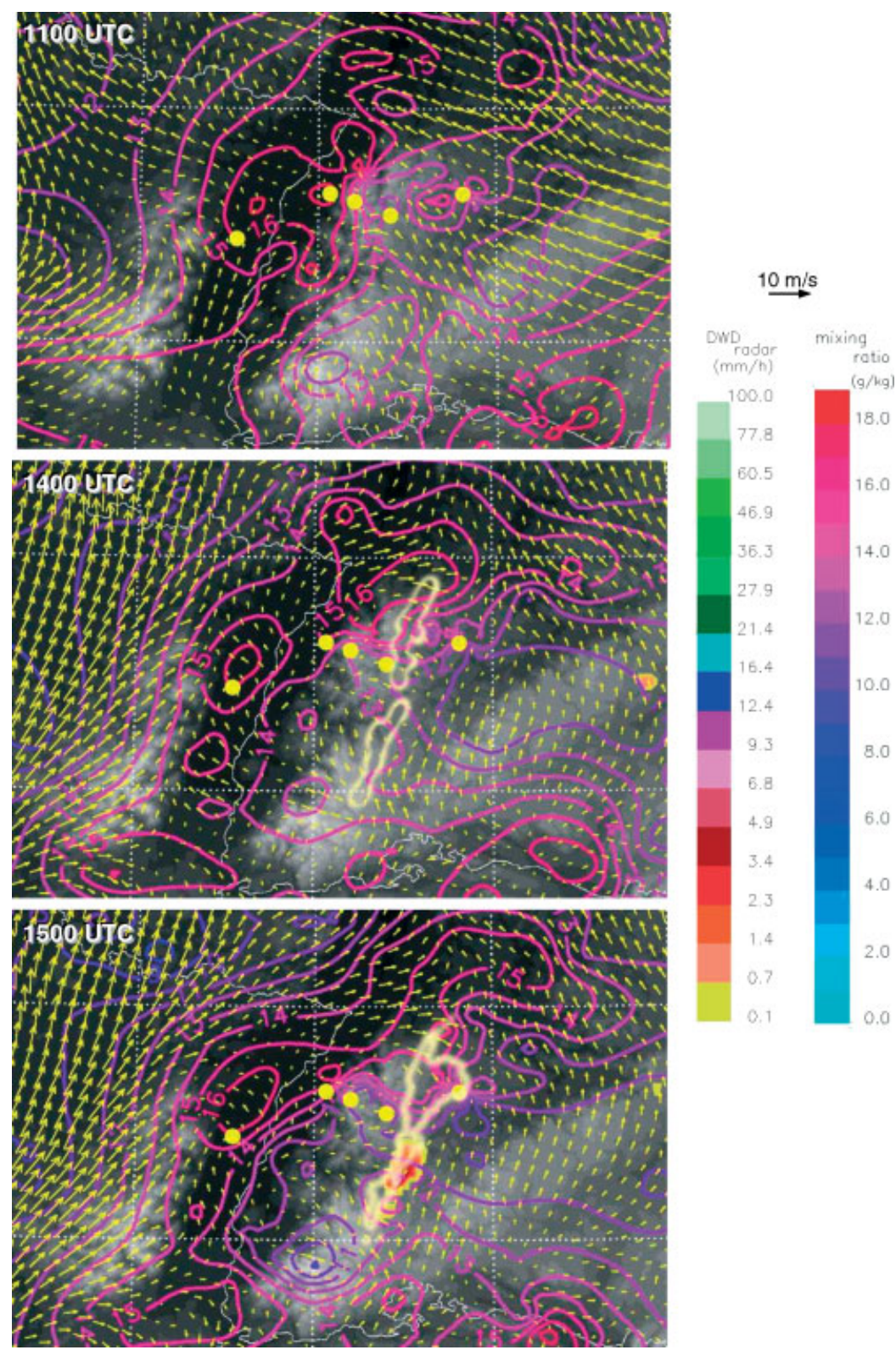

Figure 3. Water-vapour mixing ratio at $2 \mathrm{~m}$ AGL and wind at $10 \mathrm{~m}$ AGL (gridded observations of VERA with $2 \mathrm{~km}$ resolution) and DWD radar precipitation composite at 1100, 1400 and 1500 UTC. Bright yellow contours show the boundaries of clouds observed with the HRV channel of MSG. The orography is shown in the background (same height scale as in Figure 1).

not constant above the region but was lower towards the ridge of the Vosges. This layer was not present west of the Vosges. Between the surface ML and the elevated layer, a dry layer with values down to $3 \mathrm{~g} / \mathrm{kg}$ was found. Above the elevated water-vapour layer, no additional layers can be distinguished and the free tropospheric air was drier, with WVMR of $\sim 0.5 \mathrm{~g} / \mathrm{kg}$ observed above $4000 \mathrm{~m}$ ASL.

The measurements of LEANDRE II at about 0915 UTC on leg L6, which was oriented along the Rhine Valley, show that the ML had a height of about $1600 \mathrm{~m}$ ASL with WVMR of about $12 \mathrm{~g} / \mathrm{kg}$ throughout the valley (Figure 5(b)). The top height of the elevated humid layer significantly differed along L6: $2700 \mathrm{~m}$ ASL in the southern part, $3400 \mathrm{~m}$ ASL in the northern part. The legs L7 and L8 were along the western flank of the Black Forest and above its ridge. Supersite $\mathrm{H}$ was passed at about 0930 UTC (Figure 5(c) and (d)). Comparing L1 with L7 and L8 one can see that the dry layer, which had separated the ML near the ground and the elevated water-vapour layer, had now nearly disappeared.
On the second flight, LEANDRE II made measurements along L9 in the Rhine Valley (Figure 5(e)) on nearly the same track as about 1.5 hours earlier on L6 but in the opposite direction. Now a significantly lower ML height of $\sim 1100 \mathrm{~m}$ ASL was found. The decrease in ML height can be explained by the presence of a residual moist layer in the morning. In the first third of L9, the elevated humid layer above the ML was present, while LEANDRE II observed drier air after 1146 UTC above the ML. It can be concluded that the air mass seen in the morning already west of the Vosges (Figure 5(a) and other LEANDRE II legs which are not shown here) had now reached the middle of the Rhine Valley. The following measurements above the Vosges all confirm the presence of drier air west of and above the ridge and accumulated moister air at the eastern flank towards the Rhine Valley.

Figure 6 shows the time-height cross-section of the WVMR obtained with BASIL at supersite $\mathrm{R}$ in the Rhine Valley. The WVMR inside the ABL increased up to $15 \mathrm{~g} / \mathrm{kg}$ at $500 \mathrm{~m} \mathrm{ASL} \mathrm{(ca.350} \mathrm{m}$ above ground level (AGL)) around 

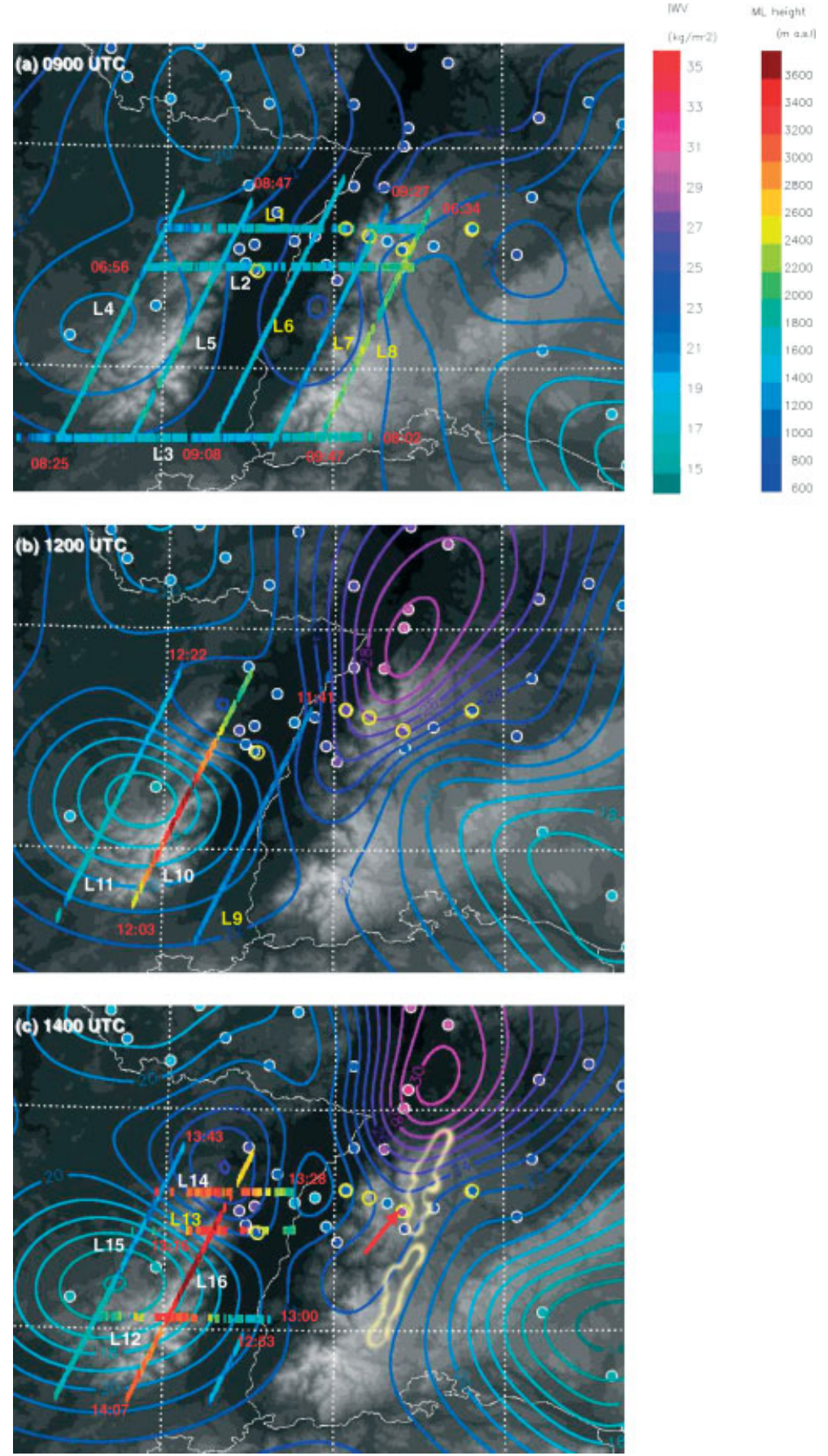

Figure 4. Contour lines show the distribution of IWV determined with the GPS network in the region at (a) 0900, (b) 1200, and (c) 1400 UTC on 15 July 2007. IWV measurements of the GPS station are shown as filled circles. IWV contours are interpolations from the GPS measurements with $2.8 \mathrm{~km}$ horizontal resolution. COPS supersites are marked with open yellow circles; a red arrow marks supersite $\mathrm{M}$ which shows $\sim 25 \%$ larger GPS-IWV than the adjacent stations due to its location in a convergence zone with towering cumulus clouds. Height of the moisture layer (ML) measured with LEANDRE II (colour scale) between (a) 0643 and 0957 UTC, (b) 1141 to 1237 UTC, and (c) 1300 to 1419 UTC on 15 July 2007. The gradient height was determined with the Haar-wavelet technique. Numbers of the flight legs L1 to L16 are given (yellow letters mark legs which are shown in Figure 5 below). Red numbers at the beginning of each leg denote the start times. The background shows the orography. Bright yellow contours mark clouds.

1300 UTC. The ground values of VERA show a similar value (Figure 3). Measurements were made with the $\mathrm{UHOH}$ water-vapour DIAL over supersite $\mathrm{H}$ on Hornisgrinde peak between about 0625 and 1800 UTC (Figure 7). Data were available from about 1500 to $5000 \mathrm{~m}$ ASL. The ABL moisture was lower at Hornisgrinde than at supersite R with $<12 \mathrm{~g} / \mathrm{kg}$ at $1500 \mathrm{~m}$ ASL (350 $\mathrm{m} \mathrm{AGL).}$

There were two moist layers in the morning between 0600 and 0900 UTC over supersites R and H, in agreement with the measurements of LEANDRE II (Figure 5(a), leg
L1). While the top of the lower moist layer was observed at $\sim 1400 \mathrm{~m}$ ASL with not much change during this period, the height of the second elevated layer decreased over both stations (bottom heights from $3000 \mathrm{~m} \mathrm{ASL}$ at 0630 UTC to $1800 \mathrm{~m}$ at $0900 \mathrm{UTC})$. At about 1300 UTC, this elevated moist layer had merged with the residual moist layer so that the atmosphere above $2000 \mathrm{~m}$ ASL became significantly drier at both supersites $\mathrm{R}$ and $\mathrm{H}$.

While the residual moist and elevated moist layers stand out clearly in all water-vapour lidar measurements, the 


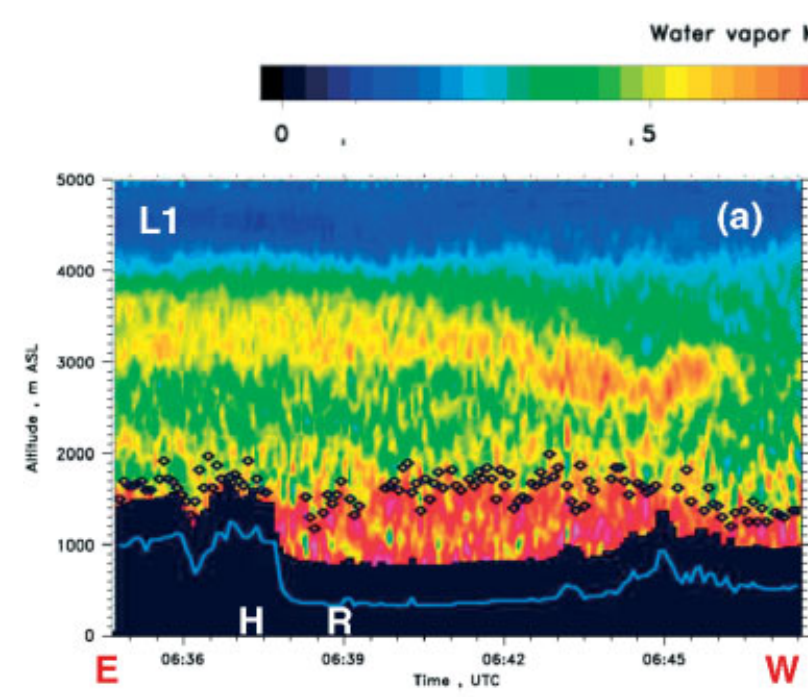

xng Ratio, g/kg

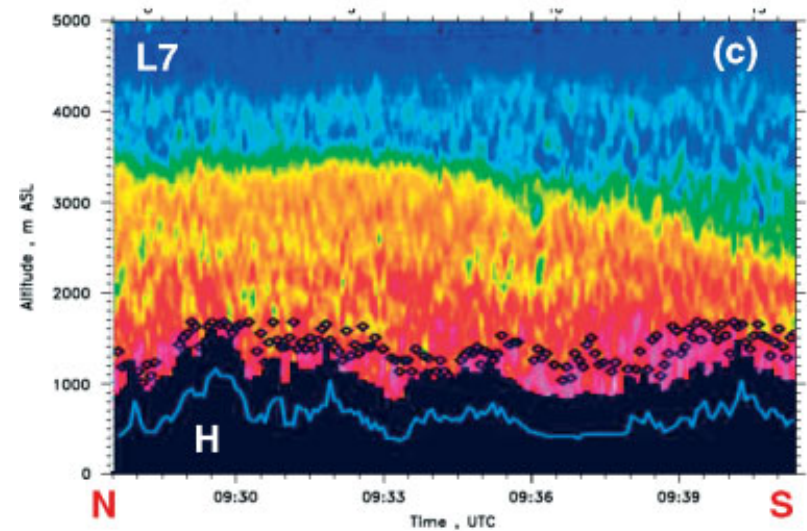

(c)
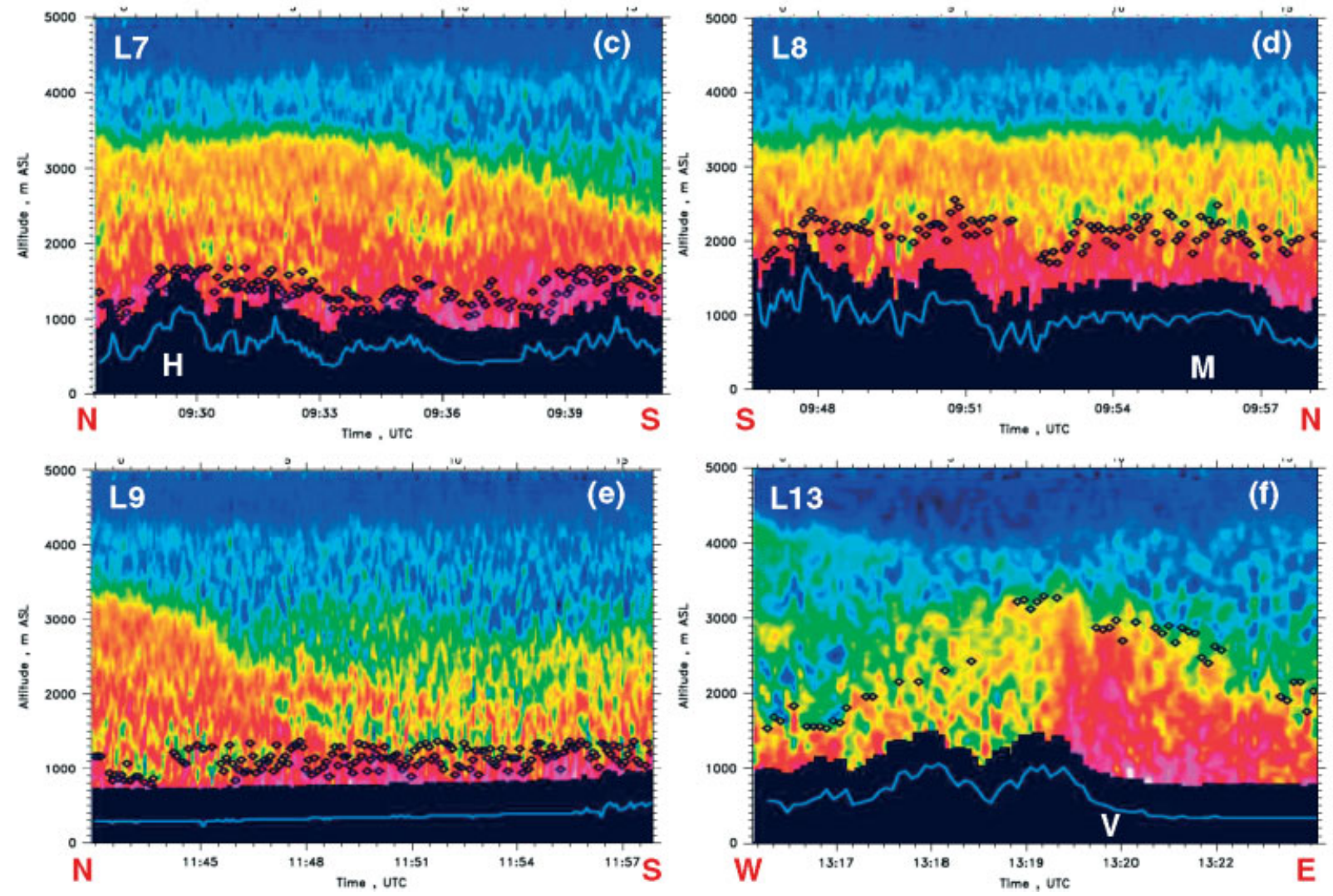

Figure 5. (a)-(f) Water-vapour measurements of LEANDRE II on the flight legs L1, L6, L7, L8, L9 and L13 (see Figure 4 for locations of the legs). Black diamonds mark the height of the moist layer determined with the Haar-wavelet technique. White letters at the bottom mark supersite overpasses; brown letters show the directions of the flights. A blue line shows the height of the ground. Regions in black are without data.

UHOH DIAL data with their high signal-to-noise ratio reveal even more details. In total, five layers are found in the UHOH DIAL data at 0800 UTC with top heights of $\sim 1500$, 1900, 3500, 4100 and $4600 \mathrm{~m}$ ASL (see numbered circles in Figure 7).

\subsection{Boundary-layer height and lids}

The structures of the water-vapour field are related to features in the temperature field, i.e. the layer boundaries are marked by temperature gradients at the top of the ABL and in the free troposphere.

Figure 8 shows ABL height at COPS supersites V, R, M and $\mathrm{H}$ between $\sim 0600$ and 1800 UTC on 15 July 2007 derived with elastic backscatter lidar data and with radiosoundings (see Figure 1 for the supersite locations). Regarding ABL height values calculated from the radiosondes, we took the lowest inversion level above ground (Figure 9). For the determination of ABL height time series from the lidar data at the supersites, we applied the Haar-wavelet-technique on the elastic backscatter data (Pal et al., 2010) which determines the largest gradient of the measured backscatter profiles. Provided that no strong residual aerosol layer is present from the previous day, the largest gradient in the elastic backscatter data coincides with the ABL top height because the aerosols act as tracers of uplifted air from the ground. 


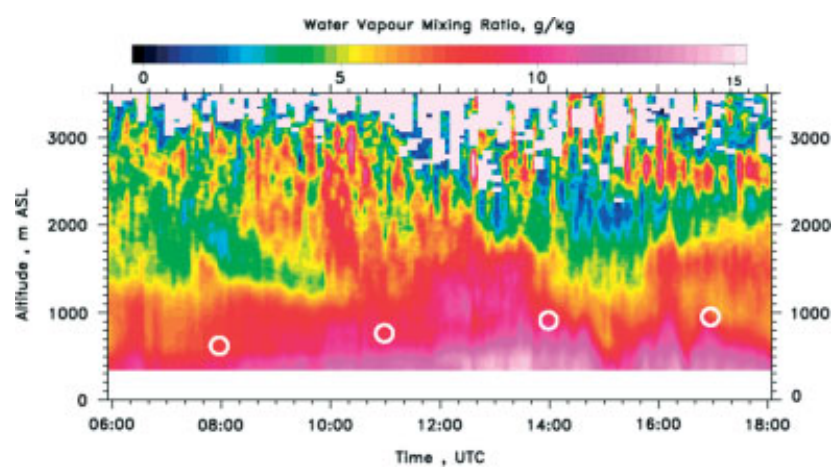

Figure 6. Water-vapour mixing ratio measured with the Raman lidar BASIL at supersite R. White circles mark the ABL height determined from radiosoundings at the same site.

Backward trajectories (not shown here) suggest that moist and aerosol-loaded air above the boundary layer was advected from the Mediterranean and possibly even the western Sahara to the COPS region during IOP 8b. In the presence of these significant residual aerosols, the determination of ABL signatures is indeed a complicated task with aerosol lidar, although not impossible.

The difference in ABL height depending on the different elevations of the supersites can be clearly seen in Figure 8, especially at supersite $\mathrm{H}$ and the neighbouring supersite $\mathrm{R}$ at a distance of just $10.7 \mathrm{~km}$; the $\mathrm{ABL}$ height data of both supersites in the Rhine Valley ( $\mathrm{R}$ and $\mathrm{V}$ ) are in closer agreement. The ABL height values above the stations in the Rhine Valley and supersite $\mathrm{H}$ show some signs of dependence on insolation, i.e. higher values are found at around noon than in the morning. While the ABL height changes at all these three stations within about $700 \mathrm{~m}$ in the course of the day, the ABL height at supersite $M$ shows differences of nearly $2000 \mathrm{~m}$. Here a large increase from $1300 \mathrm{~m}$ ASL in the morning to $\sim 3200 \mathrm{~m}$ ASL at 1300 UTC was observed. At 1300 UTC, clouds are detected by the lidars at supersite $\mathrm{M}$ with base heights at the ABL top height (some larger values are from sides of the cumulus clouds in the laser beam). From 1300 to about 1435 UTC, the ceilometer in Freudenstadt (see Figure 1 for location) detected clouds with base heights descending from 2150 to 1900 m ASL (agreeing approximately with the LCL values of VERA at this location). The ceilometer at supersite $S$ did detect cumulus clouds briefly with cloud-base height of $\sim 2600 \mathrm{~m}$ ASL at 1535 UTC when clouds passed over the site. The cirrus anvil of the convective cell was also detected with cloud-base heights between 8850 and $11750 \mathrm{~m} \mathrm{ASL}$ (not shown here).

The potential-temperature profiles derived from the radiosondes show a number of additional strong gradients besides the inversion at the ABL top (Figure 7). These can be related to layer boundaries present in the lidar data. It can be seen that the determination of the ABL height with radiosonde profiles is sometimes ambiguous due to the presence of several gradients, e.g. at supersite $\mathrm{H}$ at 0800 and 1100 UTC. Furthermore, it is interesting to note that the ABL heights found at supersite $\mathrm{H}$ are always accompanied by gradients at approximately the same heights in the profiles of the radiosondes launched at supersites $\mathrm{R}$ and $\mathrm{M}$. Mostly, the gradient at supersite $\mathrm{H}$ is a little bit elevated compared to $\mathrm{R}$ and $\mathrm{M}$ by about 100 to $200 \mathrm{~m}$ (at $\sim 0500,0800,1100$ and $\sim 1400$ UTC) which is much less than the differences in ground elevation of nearly 1000 and about $500 \mathrm{~m}$ between
$\mathrm{R}$ and $\mathrm{H}$, and $\mathrm{H}$ and $\mathrm{M}$, respectively. Between lids 2 and 3, a well-mixed elevated layer is present above supersite $\mathrm{H}$ at 0500, 0800 and 1100 UTC. This layer is also characterized by increased water-vapour mixing ratio. In the late afternoon, a second smaller lid at $1600 \mathrm{~m}$ is seen in the profile from the radiosonde launched at supersite $\mathrm{M}$. This height corresponds to similar gradients at the neighbouring supersites at the same height.

Between $\sim 1300$ and 1400 UTC, the lidars detected clouds above supersite $\mathrm{M}$ with a cloud-base height corresponding to the height of the ABL of about $3000 \mathrm{~m}$ ASL (Figure 8), which confirms that the ABL extends to a comparatively large depth of $\sim 2500 \mathrm{~m}$ here.

The humidity layers observed by the lidars agree with the lids seen in the local radiosonde profiles (Figure 9) with layer 1 corresponding to the ABL height. The gradient of the potential-temperature profile above supersite $\mathrm{H}$ was measured continuously by the $\mathrm{UHOH}$ rotational Raman lidar (RRL) (Figure 10). Strong lids with potentialtemperature gradients larger than $2 \mathrm{~K}$ per $100 \mathrm{~m}$ were observed between 3000 and $4000 \mathrm{~m}$ ASL corresponding to the top height of the elevated mixed and moist layer. Much drier air was observed from Hornisgrinde above these lids with WVMR less than $2 \mathrm{~g} / \mathrm{kg}$ (Figure 7). Data from the local radiosondes were used to determine the wind profile. The lower layer was advected from the southeast at altitudes between 1500 and $2000 \mathrm{~m} \mathrm{ASL}$; the second, less moist layer from the southwest. The bottom of the second layer descended and the dry layer between both moist layers disappeared at around 0845 UTC. At supersite R the bottom of the elevated layer reaches the lower moist layer later than at supersite $\mathrm{H}$; the dry layer can be distinguished until 1000 UTC (Figure 7). The elevated moist layer is identical in height with the elevated mixed layer seen in the potentialtemperature profiles between lids 2 and 3 from 0500 to 1100 UTC (Figure 9).

Between 1000 and 1100 UTC as well as between 1140 and 1300 UTC, clear-air updraughts were observed by the KIT Doppler lidar in the lower free troposphere up to $3700 \mathrm{~m}$ ASL (Figure 11). The updraughts in the second period were less intense (up to $1.5 \mathrm{~m} / \mathrm{s}$ ) than earlier (up to $3 \mathrm{~m} / \mathrm{s}$ ). At $\sim 1230$ UTC, the moist layer extended up to $3500 \mathrm{~m} \mathrm{ASL}$ above supersite $\mathrm{H}$ (white arrow in Figure 7). In agreement with this boundary, a strong lid appeared in the data of the UHOH RRL (dashed line in Figures 7 and 10). Between 1320 and 1400 UTC a similar lid structure is found in the RRL data corresponding to a less pronounced moisture layer. We believe that these lids between 3000 and $3500 \mathrm{~m} \mathrm{ASL}$ separating moister air from dry air above were barriers that the shallow convection in the convergence zones had to penetrate.

At the time when the gap between the two moist layers above supersite $\mathrm{H}$ had just vanished, strong updraughts were present above supersite $H$ between 1000 and 1100 UTC (Figure 11). Profiles of latent-heat flux were calculated by correlating the lidar measurements of vertical wind and WVMR (Wulfmeyer, 1999) (Figure 12). Values of 150 to $260 \mathrm{~W} / \mathrm{m}^{2}$ were measured between 1005 and 1100 UTC up to the capping temperature lid at $1900 \mathrm{~m}$ ASL. A second maximum in the latent-heat-flux profile is present between 2200 and $3100 \mathrm{~m}$ ASL with unusually high values of up to $\sim 500 \mathrm{~W} / \mathrm{m}^{2}$ at $2400 \mathrm{~m}$ ASL.

The radiosondes launched at supersites $\mathrm{V}, \mathrm{R}$ and $\mathrm{H}$ at 1400, 1430 and 1423 UTC, respectively, show a further lid 


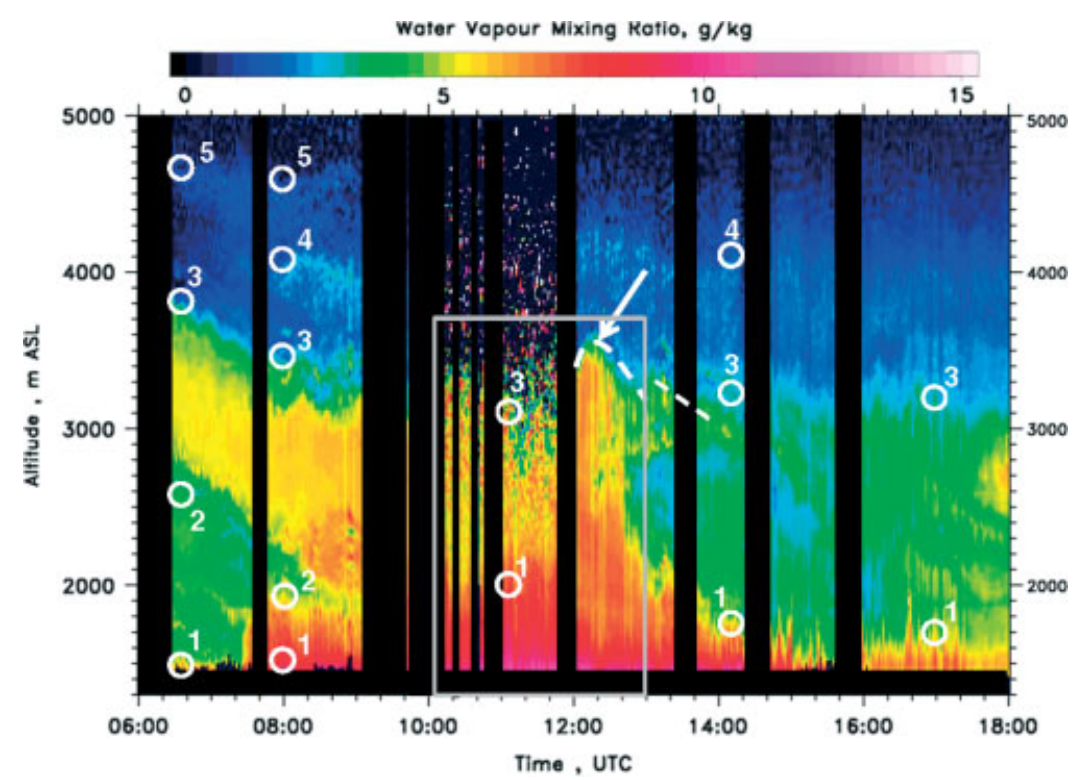

Figure 7. Water-vapour mixing ratio measured with UHOH DIAL at supersite H. Grey box: period and height region of vertical velocity plot shown in Figure 11 below. White arrow: plume of moist air which is capped. White circles mark potential-temperature lids found with radiosoundings at the same site. Dashed lines mark capping temperature lids found with the $\mathrm{UHOH}$ rotational Raman lidar. Regions in black are without data.

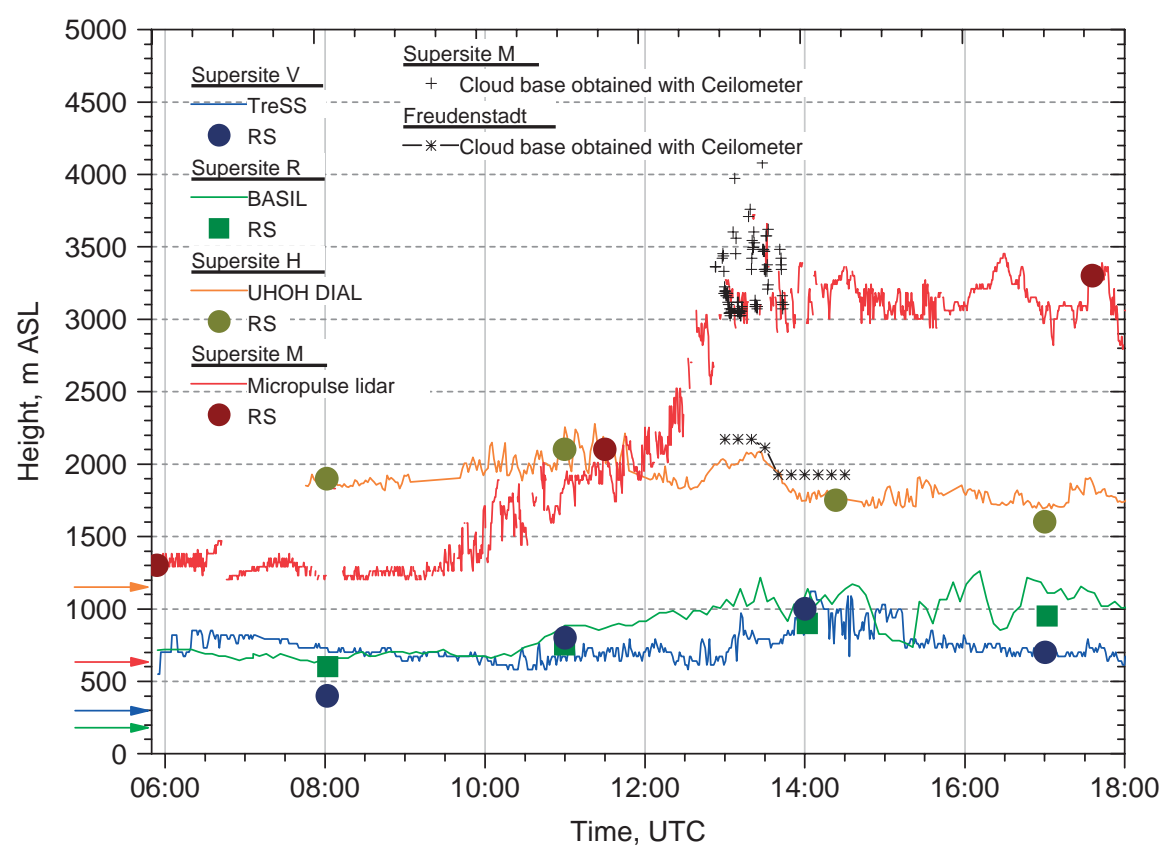

Figure 8. ABL height determined with lidar and radiosonde measurements at the supersites V, R, $\mathrm{H}$ and $\mathrm{M}$. Arrows indicate the ground height of each supersite.

at about $4500 \mathrm{~m}$ ASL. This lid approximately corresponds to the top of a moisture layer (Figure 5(f)).

\subsection{Lifting condensation level}

Obviously, the updraughts observed above Hornisgrinde (see previous section) were not sufficient for enough moisture to reach the condensation level at this location because no clouds formed.

LCL is the height where condensation occurs after a parcel has been lifted adiabatically. Lower values occur where the air is moist, for example. The LCL distribution in the area is shown in Figure 13. LCL was calculated solely with VERA data at $2 \mathrm{~m}$ AGL. Since the dew-point depends on pressure, hydrostatic equilibrium was assumed to derive the pressure profile at each grid point with the ground-level pressure of VERA. The resulting LCL field was finally combined with elevation data to derive the LCL data in units of $m$ AGL, which we denote as LCL-AGL. It is found that lower values of LCL-AGL are present generally above higher elevations. It is interesting to note that LCL-ASL (not shown) is also not constant; higher values are found above the mountains.

In the analyses of 1100 and 1400 UTC, the LCL-AGL in the Vosges and Black Forest region shows quite similar values. However there is an exception from the above-mentioned relation of LCL-AGL and elevation at 1100 UTC in the northern Black Forest. There are large values of LCL-AGL of up to $1800 \mathrm{~m}$ compared to values of $\sim 1000 \mathrm{~m}$ elsewhere in 

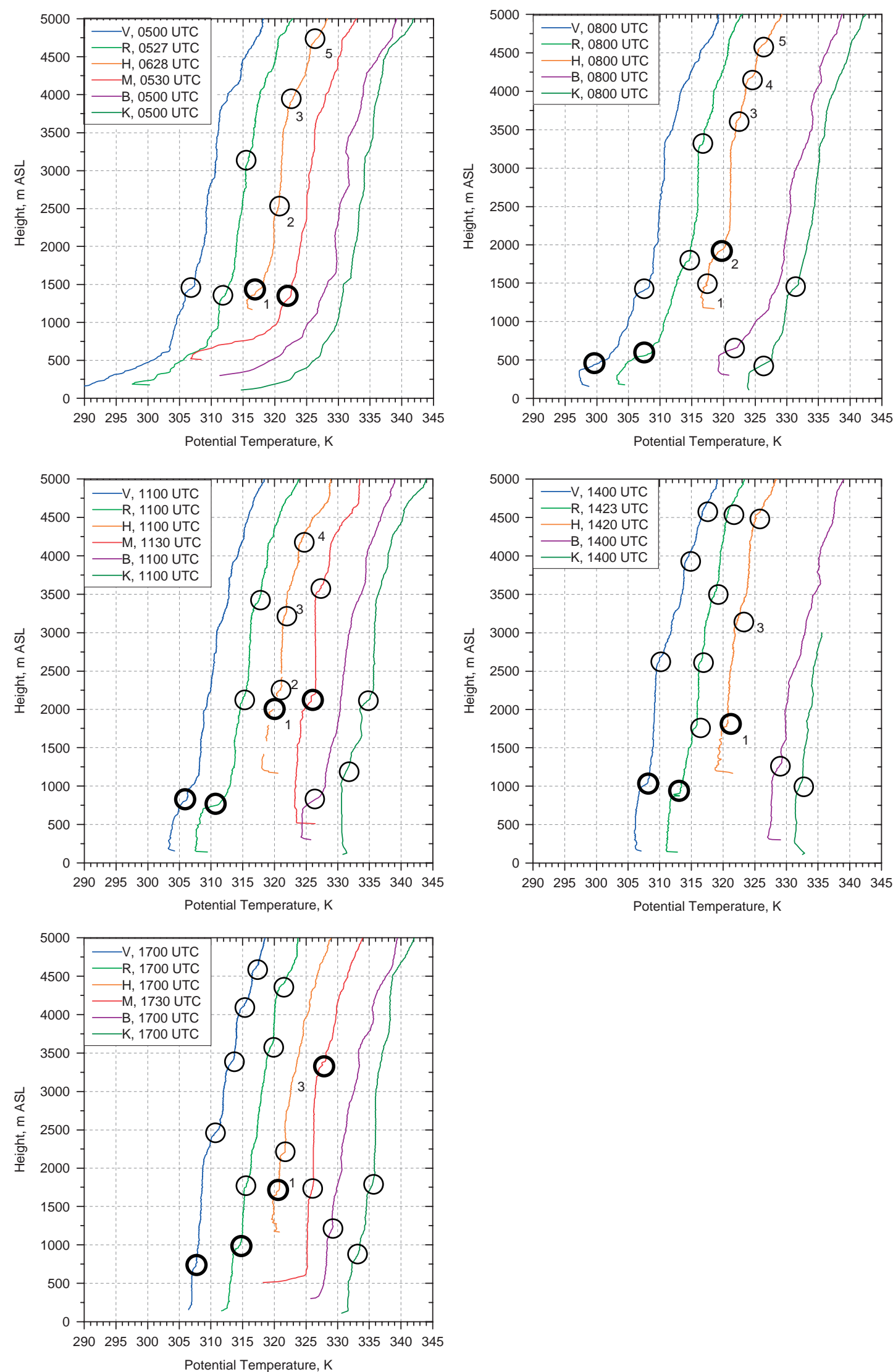

Figure 9. Potential temperature profiles measured with radiosondes launched at supersites V, R, H and M and at Burnhaupt (B) and Karlsruhe Institute of Technology (K). An offset of 5, 10, 15, 20 and $25 \mathrm{~K}$ was applied to R, H, M, B and K, respectively. Circles mark larger potential temperature gradients; thick circles denote the ABL heights shown in Figure 8. 


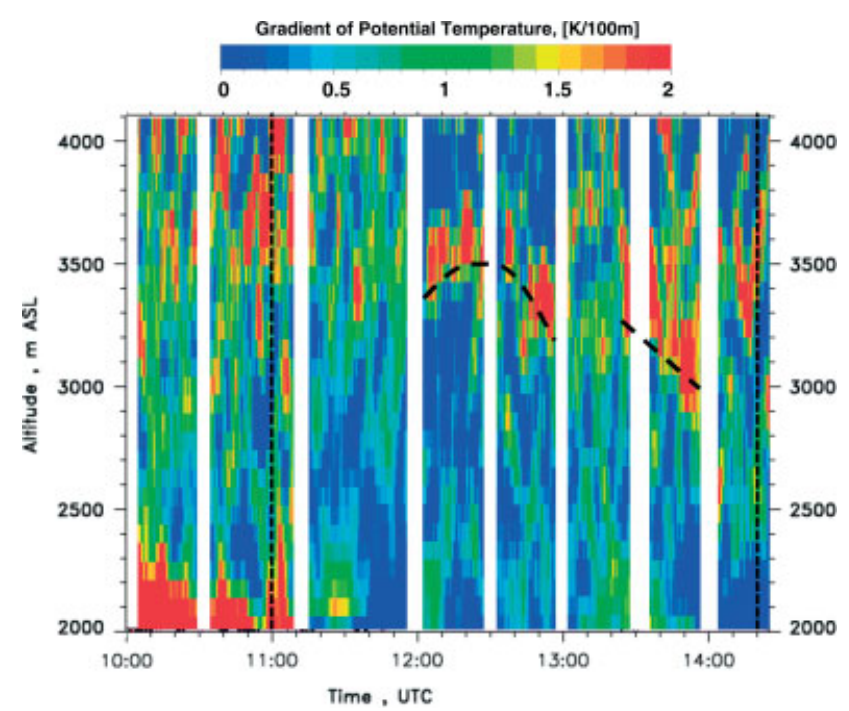

Figure 10. Potential temperature gradient measured with the rotational Raman lidar of $\mathrm{UHOH}$ at supersite H. Dashed vertical lines: time of radiosonde launched at this site. Dashed thick lines: capping lids which inhibit vertical exchange; heights of these correspond to gradient in watervapour mixing ratio (see Figure 7).

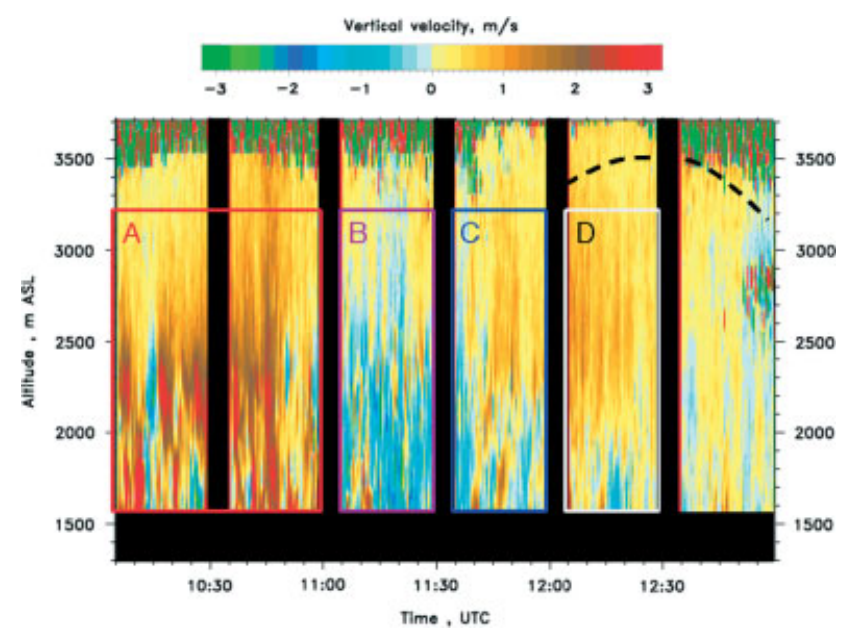

Figure 11. Vertical velocity measured with KIT Doppler lidar at supersite H. Four periods for which latent heat fluxes were calculated are marked with A to D. Dashed thick line: capping lid marked in Figure 10.

the mountains, corresponding to higher values of potential temperature at the ground in this region.

At Hornisgrinde, VERA shows an LCL value of $1800 \mathrm{~m}$ AGL corresponding to about $3000 \mathrm{~m}$ ASL. The lids observed at supersite $\mathrm{H}$ (see section 0 ) reached up to about $3500 \mathrm{~m}$ ASL at 1230 UTC and moisture with WVMR up to $8 \mathrm{~g} / \mathrm{kg}$ was transported to $>3000 \mathrm{~m} \mathrm{ASL}$. This, however, is a much lower value than the $14 \mathrm{~g} / \mathrm{kg}$ found at the ground (Figure 3 ). This difference in WVMR explains why no clouds formed even though the updraughts reached the LCL. The Doppler lidar (Figure 11) reveals different structures in the vertical wind fields inside the ABL and above. There were up- and downdraughts inside the ABL, like those expected for a convective boundary layer, while the observed updraughts in the free troposphere seem to originate from the top of the $\mathrm{ABL}$, i.e. above about $2000 \mathrm{~m}$ ASL.

Assuming similar development of the convective boundary layer in both parts of the Black Forest (BF), the difference in LCL may explain why clouds formed later in the northern

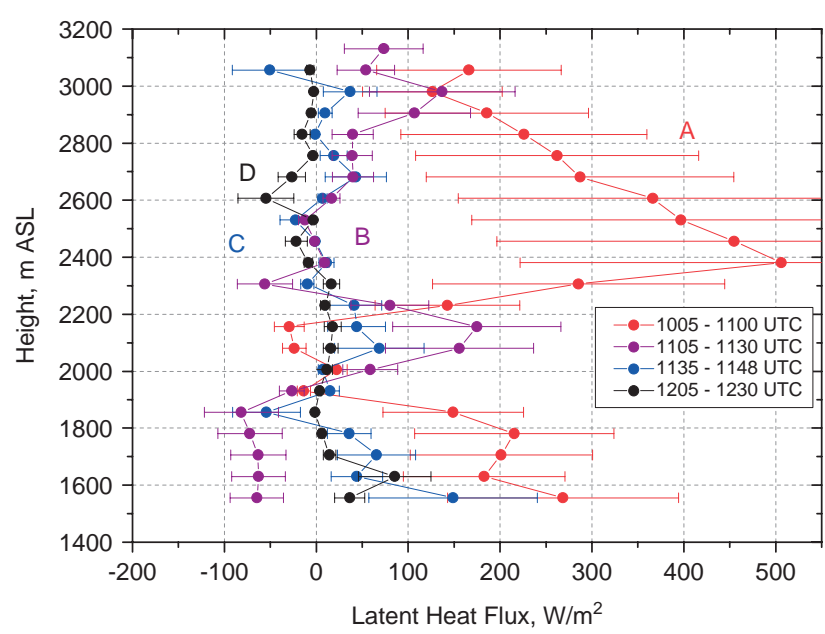

Figure 12. Latent heat flux calculated with $\mathrm{UHOH}$ water-vapour DIAL and Forschungszentrum Karlsruhe Doppler lidar data. Error bars show sampling errors. Profile A shows the latent heat flux during a period when a strong updraught was present above this site.

BF than in the southern part. At 1400 UTC, LCL-AGL values had generally increased compared to 1100 UTC because potential temperature increased at the ground while WVMR had decreased, again with the exception of the northern BF, where lower values were found at 1400 UTC compared to 1100 UTC.

The LCL-AGL field at 1400 UTC separates lower values in the northern BF and southern BF ( 1400-1800 m AGL) from high values of $>2000 \mathrm{~m}$ AGL in between. These heights are obviously not reached by the boundary layer, so that separate cloud lines in the northern and southern BF were present. At 1500 UTC, after CI took place, this separating tongue of high LGL-AGL had even strengthened and LCL had become larger also in the southern BF which might also explain why the third cell, which was initiated at 1450 UTC, had only a limited lifetime.

\subsection{Discussion of moisture transport and convection initiation}

The strong flow from southwest to northeast found near the surface west of the Vosges (Figure 3) intensified between 1100 and 1500 UTC. It advected relatively dry air from the Mediterranean into the region west of the Vosges. The radiosondes launched in Nancy, about $60 \mathrm{~km}$ west of the Vosges, at 0000, 0600, 1200 and 1800 UTC (not shown) support the VERA wind data and show that this feature had the characteristics of a low-level jet. If the advected air had also been warmer in addition, this fact would have inhibited convection further. The soundings at Nancy, however, show no significant change in temperature. Figure 5(f) illustrates the result of the dry-air advection showing the measurements of leg L13 which passed supersite V.

East of the Black Forest, southeasterly winds were observed, confirming the large-scale convergence above the COPS region. At 1100 UTC, the winds in the Rhine Valley were mostly southwesterly, following the dominant flow west of the Vosges, but, already at this time, thermally induced secondary wind systems were visible that were directed from the Rhine Valley towards the Vosges and BF. These systems intensified later due to the mostly cloud-free situation with high insolation. As a result, circumfluent 

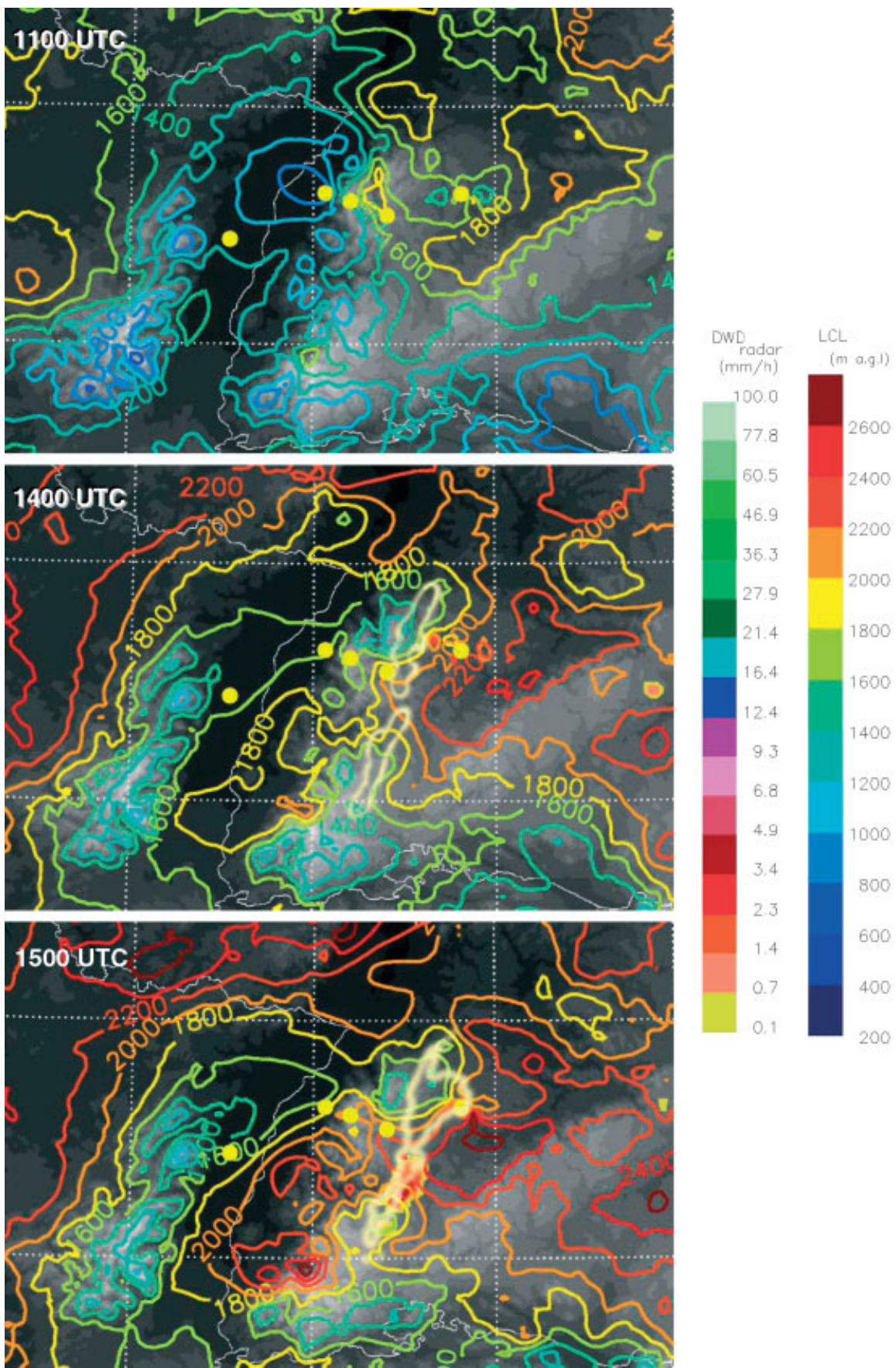

Figure 13. Same as Figure 3 but with VERA lifting condensation level (LCL) in m AGL.

surface winds formed around the southern and northern BF which met the southeasterly winds east of the Black Forest resulting in local convergence zones. Clouds formed above these convergence zones. In the southern BF, the location of the convergence zone was more stationary than in the northern BF, which allowed for constant advection of latent and sensible heat.

Combining the VERA surface fields of moisture and wind, Figure 14 shows MFD. At 1100 UTC, regions of MFC above the northern and southern Vosges and the northern and southern BF are found (white arrows in Figure 14, values $\left.>6 \cdot 10^{-3} \mathrm{~g} /(\mathrm{kg} \cdot \mathrm{s})\right)$. In the Rhine Valley and around the BF, regions of high MFD were present, with maxima generally coinciding with the large valleys at the flanks of the mountains. This finding agrees with the development of thermal flows into the mountains. At 1400 UTC, the MFC values had decreased over the Vosges but increased over the BF. Above the BF, LCL values (see Figure 13) were now reached within two larger bands, one in the northern and one in the southern BF with a gap in between. The formation of clouds resulted in latent heat release which can be assumed to give a positive feedback on convergence near the ground by intensifying the thermal updraughts. Furthermore, it can be assumed that the detrainment at the cloud boundaries also moistens higher altitudes and increases continuously the chances for CI later. One hour later at 1500 UTC, when deep convection had just been initiated, a maximum in MFC is found southwest of the precipitating cell; this MFC maximum is surrounded by maxima in MFD. The apparent displacement of the MFC zone (which is stationary between 1400 and 1500 UTC) and precipitation of about $15 \mathrm{~km}$ can be explained by drift of the uprising air in the cell with 

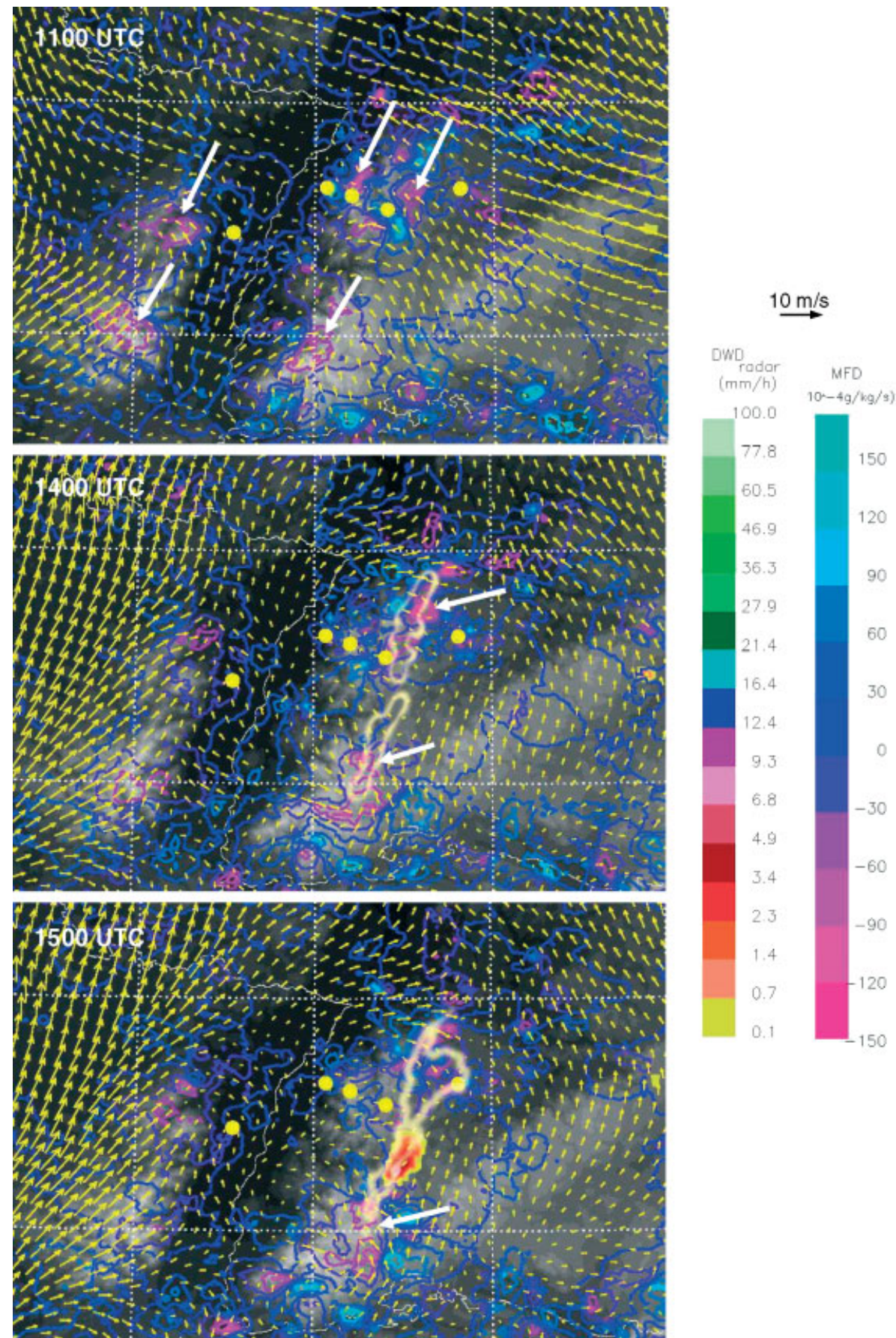

Figure 14. Same as Figure 3 but with VERA moisture flux divergence (negative values show moisture flux convergence, MFC); white arrows mark MFC zones discussed in the text.

the large-scale flow in the free troposphere (this motion is confirmed by the MSG images, see Aoshima et al. (2008)) and corresponding displacement of the rainfall below the cell compared to the ground at those heights at which the radar scans the cell ( $2000 \mathrm{~m}$ ASL).

Radial-velocity fields measured with the DWD radar at Feldberg (the highest peak in the southern Black Forest) picked up the convergence zone in their horizontal scans $\left(0.5^{\circ}\right.$ elevation angle), because the convergence zone was favourably aligned to the radial velocity field of the radar (Figure 1). While the MFD of VERA was obtained from the wind and moisture measurements near the surface, the radar measurements were made at a height of $2000 \mathrm{~m}$ ASL. The correspondence of surface convergence and radial radar convergence is striking. It gives confidence in the MFC values of VERA and in using this parameter in the investigation of dynamics in complex terrain - even though care still has to be taken to use the surface analysis as only one source of information.

A comparison of the regions with high MFC between the southern and northern BF shows that the zones with convergence in the southern BF were more stationary on this day than in the northern BF where the zones of MFC and MFD were also smaller. For instance, VERA reveals that several zones with MFC are present in the northern BF at 1100 UTC (see Figure 14, upper panel). It has been proposed that an east-to-west moving synoptically induced mesoscale convergence zone crossed the northern BF on this day (see 
Figs. 6 and 10 of Kalthoff et al. (2009)) which superimposed with thermally driven circulation systems. This moving line was not found in the VERA analysis.

For investigating the variability of moisture and wind close to the location of CI, in situ measurements of moisture and wind obtained with the BAe-146 and Do-128 aircraft are discussed in the following.

The BAe-146 aircraft was operated from 1300 to 1650 UTC on 15 July 2007. Figure 15(a) and (b) show wind and WVMR measurements, respectively, during one leg made at about $1700 \mathrm{~m}$ ASL between supersites $\mathrm{H}$ and $\mathrm{M}$ at around 1415 UTC, just before convection was initiated about $15 \mathrm{~km}$ east of this leg. Note that this flight is within the ABL (Figure 8). The southwesterly flow into the convergence line can be seen. A comparison of this leg with a leg flown about 30 minutes earlier at the same location (not shown) shows that the inflow intensified. Vertical velocity measurements reveal some updraughts up to $3.5 \mathrm{~m} / \mathrm{s}$, values which agree with the measurements of the Doppler lidar at supersite $\mathrm{H}$ (Figure 11); on other legs over the Rhine valley no significant updraughts were observed (not shown). The WVMR shows significant differences in the region. While a moist region with values $\sim 10 \mathrm{~g} / \mathrm{kg}$ was observed northeast of the supersite transect, the air in the southern region was much drier with values of as low as $\sim 3 \mathrm{~g} / \mathrm{kg}$. Note that a similar north-south structure in water vapour is found in the VERA moisture data at the ground, although there were higher values of WVMR at the ground (Figure 3). Also the GPS-IWV field shows increased values north of the Black Forest. After 1430 UTC, the BAe-146 aircraft flew several legs through the clouds north of the major cell (Huang et al., 2011).

The Do-128 aircraft performed two flight missions on 15 July 2007: one in the morning between 0730 and 0900 UTC (not shown here; see Kalthoff et al. (2009) for figures of these data) and the second in the afternoon between 1215 and 1500 UTC. Figure 15(c) and (d) show the Do128 measurements of moisture and wind between 1331 and 1434 UTC. The Do-128 flew mainly in parallel legs to the cloud line in the northern Black Forest and performed measurements just below the clouds a few minutes before CI took place. The flight altitude was $2000 \mathrm{~m}$ ASL except for the leg between 1350 and 1400 UTC over the Rhine Valley with $1070 \mathrm{~m}$ ASL. The vertical velocity field did not show any significant updraughts or downdraughts over most of the region except along the flight track over the supersite $\mathrm{M}$ and below the clouds between 1405 and 1430 UTC where significant updraughts were observed with vertical velocity of up to $4.5 \mathrm{~m} / \mathrm{s}$. Water-vapour measurements along this track showed similar WVMR values as the BAe-146 which flew $300 \mathrm{~m}$ lower. The pattern of potential temperature showed no significant variability, with nearly constant values around 308.5 K (not shown here). The Do-128 measurements near the clouds differ from the surrounding data in addition to the presence of updraughts also by more than double the WVMR values.

In summary, the aircraft observations confirm the upward transport of moisture at the convergence zone.

\section{Conclusions}

The synthesis of data gathered from the large suite of research instruments employed during COPS has provided detailed insight into the atmospheric processes responsible for the initiation of the deep convection that occurred on 15 July 2007 (IOP 8b).

An analysis of convective indices, which were calculated using surface and GPS-IWV in addition to radiosoundings, shows that high values of CAPE were available over the Black Forest, while CIN was moderate. Thus, the atmosphere was conditioned for deep convection. Not surprisingly, the regions of maximum WVMR at the ground, maximum CAPE or minimum CIN do not coincide with the location of CI.

With the combination of three-dimensional moisture data and wind data, the location of CI in the Black Forest can be understood. Due to a cloud-free atmosphere in the morning and consequently high insolation, thermally induced wind systems developed over the Vosges and Black Forest with moisture flux divergence in the larger valleys. Over the Rhine valley, moisture flux divergence was observed between 1000 and 1600 UTC with largest values at around local noon (which is at 1130 UTC). Convergence zones were observed over both the Vosges and Black Forest mountains. VERA reveals that several zones with MFC were present in the northern Black Forest. A moving convergence zone crossing the northern Black Forest (Kalthoff et al., 2009) was not found in the VERA analysis.

LEANDRE II measurements showed that the moisture layer near the ground was significantly drier over the western part of the Vosges compared to the eastern part. GPS measurements supported this observation with relative lower values of IWV $\left(18 \mathrm{~kg} / \mathrm{m}^{2}\right)$ over this region. The lower moisture values caused higher CIN. The VERA analysis of surface fields showed MFC at the Vosges between 1000 and 1400 UTC. A few clouds developed in this region around 1125 UTC but they disappeared at around 1315 UTC. We conclude that too-low moisture values and consequently higher CIN contributed to the fact that convection remained shallow and sparse and no deep convection was initiated above the Vosges on this day.

The analysis of ABL heights showed a shallow ABL in the Rhine Valley and above supersite $\mathrm{H}$ at the ridge of the northern Black Forest. Such conditions did not support CI in this area despite high moisture values near the ground and in the boundary layer because the LCL was not reached by the ABL height. In particular, close to supersite $H$ very low values of CIN and the presence of CAPE at 1400 UTC were observed, but convection was not initiated even though latent heat fluxes of up to $500 \mathrm{~W} / \mathrm{m}^{2}$ were present at $2400 \mathrm{~m} \mathrm{ASL}$ as correlated measurements with water vapour and Doppler lidar at Hornisgrinde revealed. Capping lids between 3000 and $3500 \mathrm{~m} \mathrm{ASL}$ at 1230 UTC hindered updraughts from the top of the ABL reaching their condensation level.

The situation was different at supersite $M$ which was located just $16 \mathrm{~km}$ southeast of supersite $\mathrm{H}$. Here the ABL height reached the LCL and clouds formed. We believe that lids between 3000 and $3500 \mathrm{~m}$ ASL separating moister air from dry air above were barriers that the shallow convection in the convergence lines had to penetrate. Only at a region where circumfluent wind around the southern Black Forest formed a stationary convergence zone were these lids eventually penetrated, initiating deep convection.

The reason for the circumfluent flow around the southern Black Forest, e.g. its relation to the mountain Froude number in the presence of thermally driven mountain-valley circulations, could not be answered with the observations 


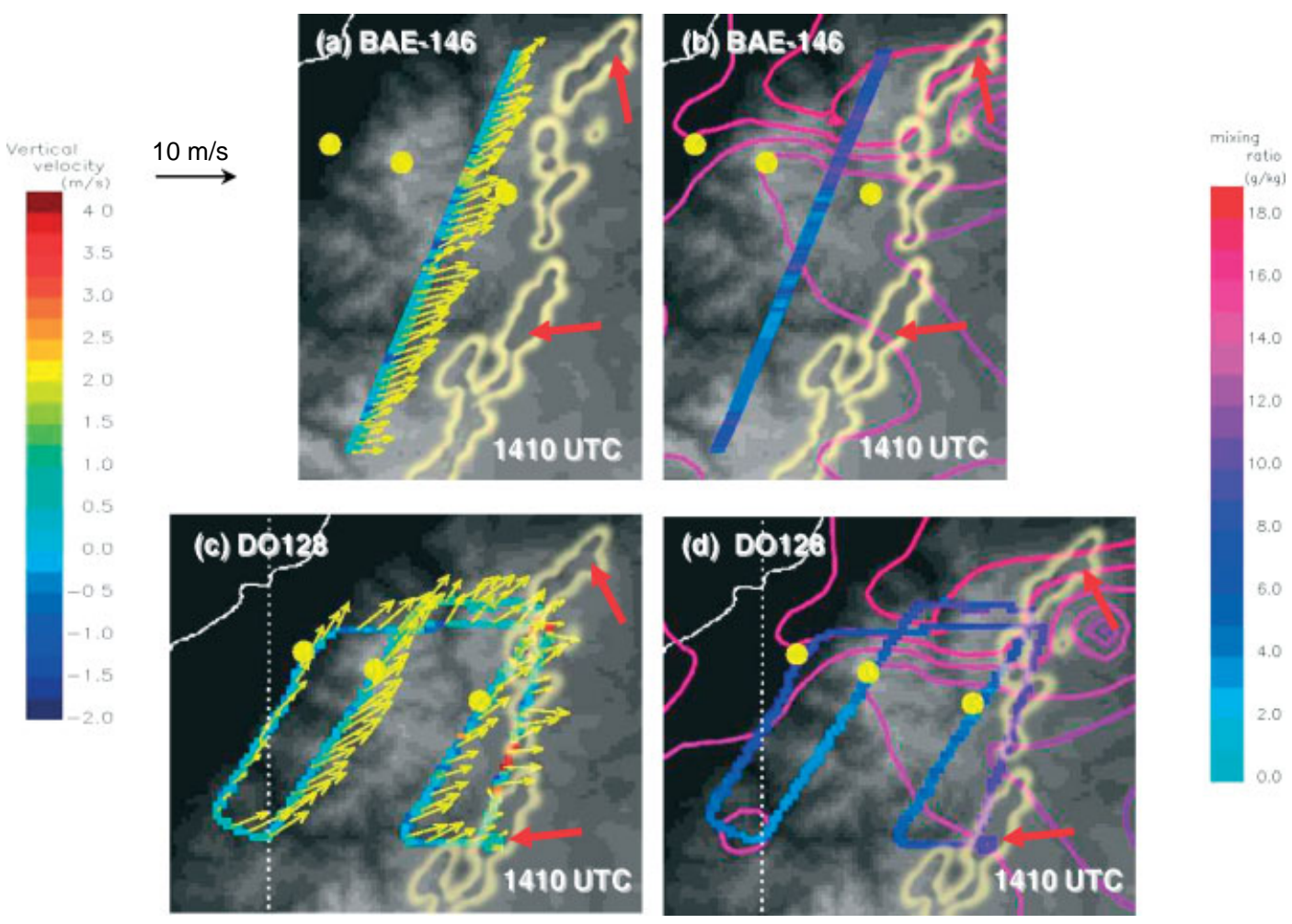

Figure 15. In situ aircraft measurements of wind and water-vapour mixing ratio with BAe-146 and Do-128 aircraft shortly before the initiation of deep convection, together with VERA water-vapour mixing ration at $2 \mathrm{~m}$ AGL at 1400 UTC (see Figure 3). Red arrows mark the locations of the precipitation cells 1 and 2 seen at 1440 UTC with the radar (cf. Figure 1). Yellow circles: COPS supersites R, H and M (from left to right). (a) Vertical wind (colours) and horizontal wind (arrows) between 1408 and 1410 UTC measured with the BAe-146 aircraft at 1670 m ASL. (b) Same as (a) but water-vapour mixing ratio. (c) Vertical wind (colours) and horizontal wind (arrows) and (d) water-vapour mixing ratio measured with the Do-128 aircraft between 1331 and 1434 UTC at $2000 \mathrm{~m}$ ASL except for the leg between 1350 and 1400 UTC over the Rhine Valley at $1000 \mathrm{~m}$ ASL.

discussed in this study; this question remains for future studies.

\section{Acknowledgements}

The COPS field phase received strong support by the Deutsche Forschungsgemeinschaft (DFG) via the Priority Programme 1167 (grants WU 356/4-1, 4-2, 4-3, 9-1), the Atmospheric Radiation Measurement (ARM) programme, Agence Nationale de la Recherche (ANR, grant ANR06-BLAN-0018-04: COPS/France), Centre Nationale de la Recherche Scientifique (CNRS)/Institut National des Sciences de l'Univers (INSU) (LEFE/IDAO programme), Centre National d'Études Spatiales (CNES) and MétéoFrance, the UK Natural Environment Research Council, the Austrian Science Foundation (FWF) (grants P 19658-N10, P 20925-N10) and all institutions the co-authors are affiliated with. The authors are grateful to INSU for the loan of the 'French' GPS station. EUFAR provided aircraft support, and EUMETSAT the MSG RSS. COPS was supported by WWRP by the endorsement as an RDP. COPS received substantial contributions from DWD, Météo-France and MeteoSwiss as well as ECMWF.

Excellent mission planning and guidance was performed by a team of scientists in the COPS operations centre with Evelyne Richard (Laboratoire d'Aérologie, Toulouse, France) being the responsible science director of IOP $8 \mathrm{~b}$. The results much profited from the forecasting skills of Cédric Hertzog (Météo-France with Synergie platform) and Marco Stoll (MeteoSwiss with NINJO platform).
Excellent support was provided by the German Air Traffic Control for the aircraft missions. The tireless efforts of the aircraft crews are highly appreciated.

Local authorities, in particularly the mayors of the communities Baiersbronn, Seebach, Sasbachwalden, and Deckenpfronn, and several land owners in the experiment region, in particular the Flugsportverein Sindelfinden e.V. and the municipal sewage plant in Achern provided most valuable assistance. All this support is acknowledged with gratitude.

The radiosonde, ceilometer, and micropulse data of supersite $M$ used in this study were obtained from the Atmospheric Radiation Measurement (ARM) Program sponsored by the US Department of Energy, Office of Science, Office of Biological and Environmental Research, Climate and Environmental Sciences Division.

\section{References}

Aoshima F, Behrendt A, Bauer H-S, Wulfmeyer V. 2008. Statistics of convection initiation by use of Meteosat rapid scan data during the Convection and Orographically-induced Precipitation Study (COPS). Meteorol. Z. 17: 921-930.

Banacos PC, Schultz DM. 2005. The use of moisture flux convergence in forecasting convective initiation: Historical and operational perspectives. Weather and Forecasting 20: 351-366.

Barthlott C, Schipper JW, Kalthoff N, Adler B, Kottmeier C, Blyth A, Mobbs SD. 2010. Model representation of boundary-layer convergence triggering deep convection over complex terrain: A case study from COPS. Atmos. Res. 95: 172-185.

Barthlott C, Burton R, Kirshbaum D, Hanley K, Richard E, Chaboureau J-P, Trentmann J, Kern B, Bauer H-S, Schwitalla T, Keil C, Seity Y, Gadian A, Blyth A, Mobbs S, Flamant C, Handwerker J. 2011. Initiation of deep convection at marginal instability in an ensemble of mesoscale 
models: a case-study from COPS. Q. J. R. Meteorol. Soc. 137(S1): 118-136, DOI: $10.1002 / q j .707$.

Behrendt A, Wulfmeyer V, Di Girolamo P, Kiemle C, Bauer H-S, Schaberl T, Summa D, Whiteman DN, Demoz BB, Browell EV, Ismail S, Ferrare R, Kooi S, Ehret G, Wang J. 2007a. Intercomparison of water vapor data measured with lidar during IHOP_2002. Part I: Airborne to ground-based lidar systems and comparisons with chilled-mirror hygrometer radiosondes. J. Atmos. Oceanic Technol. 24: 3-21.

Behrendt A, Wulfmeyer V, Kiemle C, Ehret G, Flamant C, Schaberl T, Bauer H-S, Kooi S, Ismail S, Ferrare R, Browell EV, Whiteman DN. 2007b. Intercomparison of water vapor data measured with lidar during IHOP_2002. Part II: Airborne-to-airborne systems. J. Atmos Oceanic Technol. 24: 22-39.

Behrendt A, Wulfmeyer V, Riede A, Wagner G, Pal S, Bauer $\mathrm{H}$ Radlach M, Späth F. 2009. 3-Dimensional observations of atmospheric humidity with a scanning differential absorption lidar. Proc. SPIE 7475 74750L, DOI: $10.1117 / 12.835143$.

Bennett LJ, Blyth AM, Burton RR, Gadian AM, Weckwerth TM, Behrendt A, Di Girolamo P, Dorninger M, Lock S-J, Smith VH, Mobbs SD. 2011. Initiation of convection over the Black Forest mountains during COPS IOP15a. Q. J. R. Meteorol. Soc. 137(S1): $176-189$.

Bhawar R., Di Girolamo P, Summa D, Flamant C, Althausen D, Behrendt A, Kiemle C, Bosser P, Cacciani M, Champollion C, Di Iorio T, Engelmann R, Herold C, Pal S, Wirth M, Wulfmeyer V. 2011. The water vapour intercomparison effort in the framework of the Convective and Orographically-induced Precipitation Study: airborne-to-ground-based and airborne-to-airborne lidar systems. $Q$. J. R. Meteorol. Soc. 137(S1): 325-348, DOI: 10.1002/qj.697.

Bica B, Steinacker R, Lotteraner C, Suklitsch M. 2007. A new concept for high resolution temperature analysis over complex terrain. Theor Appl. Climatol. 90: 173-183.

Browning KA, Blyth AM, Clark PA, Corsmeier U, Morcrette CJ, Agnew JL, Ballard SP, Bamber D, Barthlott C, Bennett LJ, Beswick KM, Bitter M, Bozier KE, Brooks BJ, Collier CG, Davies F, Deny B, Dixon MA, Feuerle T, Forbes RM, Gaffard C, Gray MD, Hankers R, Hewison TJ, Kalthoff N, Khodayar S, Kohler M, Kottmeier C, Kraut S, Kunz M, Ladd DN, Lean HW, Lenfant J, Li Z, Marsham J, McGregor J, Mobbs SD, Nicol J, Norton E, Parker DJ, Perry F, Ramatschi M, Ricketts HMA, Roberts NM, Russell A, Schulz H, Slack EC, Vaughan G, Waight J, Wareing DP, Watson RJ, Webb AR, Wieser A. 2007. The Convective Storm Initiation Project. Bull. Am. Meteorol. Soc. 88: 1939-1955.

Bruneau D, Quaglia P, Flamant C, Meissonnier M, Pelon J. 2001. Airborne lidar LEANDRE II for water-vapor profiling in the troposphere. I. System description. Appl. Opt. 40: 3450-3461.

Carbone RE, Tuttle JD, Ahijevych DA, Trier SB. 2002. Inferences of predictability associated with warm season precipitation episodes. J. Atmos. Sci. 59: 2033-2056.

Corsmeier U, Hankers R, Wieser A. 2001. Airborne turbulence measurements in the lower troposphere onboard the research aircraft Dornier 128-6, D-IBUF. Meteorol. Z. 10: 315-329.

Corsmeier U, Kalthoff N, Barthlott C, Behrendt A, Di Girolamo P, Dorninger M, Handwerker J, Kottmeier C, Mahlke H, Mobbs SD, Norton EG, Wickert J, Wulfmeyer V. 2011. Processes driving deep convection over complex terrain: A multi-scale analysis of observations from COPS IOP 9c. Q. J. R. Meteorol. Soc. 137(S1) 137-155, DOI: $10.1002 / q j .754$.

Craven JP, Jewell RE, Brooks HE. 2002. Comparison between observed convective cloud-base heights and lifting condensation level for two different lifted parcels. Weather and Forecasting 17: 885-890.

Crewell S, Mech M, Reinhardt T, Selbach C, Betz H-D, Brocard E, Dick G, O'Connor E, Fischer J, Hanisch T, Hauf T, Hünerbein A, Delobbe L, Mathes A, Peters G, Wernli H, Wiegner M, Wulfmeyer V. 2008. The general observation period 2007 within the priority program on quantitative precipitation forecasting: Concept and first results. Meteorol. Z. 17: 849-866.

Crook NA. 1996. Sensitivity of moist convection forced by boundary layer processes to low-level thermodynamic fields. Mon. Weather Rev. 124: 1767-1785.

Dayan U, Shenhav R, Graber M. 1988. The spatial and temporal behavior of the mixed layer in Israel. J. Appl. Meteorol. 27: 1382-1394.

De Wekker SFJ, Kossmann M, Fiedler F. 1997. 'Observations of daytime mixed layer heights over mountainous terrain during the TRACT field campaign.' Pp 498-499 in Proceedings of the 12th AMS Symposium on Boundary layers and turbulence, Vancouver, BC, Canada. American Meteorological Society.

Dick G, Gendt G, Reigber C. 2001. First experience with near realtime water vapor estimation in a German GPS network. J. Atmos. Solar-Terr. Phys. 63: 1295-1304.
Di Girolamo P, Marchese R, Whiteman DN, Demoz BB. 2004. Rotational Raman lidar measurements of atmospheric temperature in the UV. Geophys. Res. Lett. 31: L01106, DOI: 10.1029/2003GL018342.

Di Girolamo P, Summa D, Ferretti R. 2009. Multiparameter Raman lidar measurements for the characterization of a dry stratosphere intrusion event. J. Atmos. Oceanic Technol. 26: 1742-1762.

Doswell III CA. 1977. Obtaining meteorologically significant surface divergence fields through the filtering property of objective analysis. Mon. Weather Rev. 105: 885-892.

Ebert EE, Damrath U, Wergen W, Baldwin ME. 2003. The WGNE assessment of short-term quantitative precipitation forecasts. Bull. Am. Meteorol. Soc. 84: 481-492.

Fabry F. 2006. The spatial variability of moisture in the boundary layer and its effect on convection initiation: Project-long characterization. Mon. Weather Rev. 134: 79-91.

Fritsch JM, Carbone RE. 2004. Improving quantitative precipitation forecasts in the warm season: A USWRP research and development strategy. Bull. Am. Meteorol. Soc. 85: 955-965.

Gendt G, Dick G, Reigber C, Tomassini M, Liu Y, Ramatschi M. 2004. Near real time GPS water vapor monitoring for numerical weather prediction in Germany. J. Meteorol. Soc. Jpn 82: 361-370.

Groenemeijer P, Barthlott C, Behrendt A, Corsmeier U, Handwerker J, Kohler M, Kottmeier C, Mahlke H, Pal S, Radlach M, Trentmann J, Wieser A, Wulfmeyer V. 2008. Observations of kinematics and thermodynamic structure surrounding a convective storm cluster over a low mountain range. Mon. Weather Rev. 137: 585-602.

Häberli C, Groehn I, Steinacker R, Pöttschacher W, Dorninger M. 2004. Performance of the surface observation network during MAP. Meteorol. Z. 13: 109-121.

Huang Y, Blyth AM, Brown PRA, Cotton R, Crosier J, Bower KN, Gallagher MW, Jones H, Gadian AM, Choularton TW, Cardwell J, Coe H, Mobbs SD, Hagen M. 2011. Development of ice particles in convective clouds observed over the Black Forest mountains during COPS. Q. J. R. Meteorol. Soc. 137(S1): 275-286, DOI: 10.1002/qj.749.

Hudson HR. 1971. On the relationship between horizontal moisture convergence and convective cloud formation. J. Appl. Meteorol. 10: $755-762$.

Kalthoff N, Binder H-J, Kossmann M, Vögtlin R, Corsmeier U, Fiedler F, Schlager H. 1998. Temporal evolution and spatial variation of the boundary layer over complex terrain. Atmos. Environ. 32: 1179-1194.

Kalthoff N, Adler B, Barthlott C, Corsmeier U, Mobbs SD, Crewell S, Träumner K, Kottmeier C, Wieser A, Smith V, Di Girolamo P. 2009. The impact of convergence zones on the initiation of deep convection: A case study from COPS. Atmos. Res. 93: 680-694.

Kaufmann H. 2006. 'Mesoscale analysis of the moisture flux divergence in the Alpine Region,' Diploma thesis (in German), University of Vienna, 113 pp.

Khodayar S, Kalthoff N, Wickert J, Corsmeier U, Morcrette CJ, Kottmeier C. 2010. The increase of spatial data resolution for the detection of the initiation of convection: A case study from CSIP. Meteorol. Z. 19: 179-198.

Kirshbaum DJ. 2011. Cloud-resolving simulations of deep convection over a heated mountain. J. Atmos. Sci., in press, DOI: 10.1175/2010JAS3642.1.

Kossmann M, Vögtlin R, Corsmeier U, Vogel B, Fiedler F, Binder H-J, Kalthoff N, Beyrich F. 1998. Aspects of the convective boundary layer structure over complex terrain. Atmos. Environ. 32: 1323-1348.

Kottmeier C, Kalthoff N, Barthlott C, Corsmeier U, Van Baelen J, Behrendt A, Behrendt R, Blyth A, Coulter R, Crewell S, Di Girolamo P, Dorninger M, Flamant C, Foken T, Hagen M, Hauck C, Höller H, Konow H, Kunz M, Mahlke H, Mobbs SD, Richard E, Steinacker R, Weckwerth TM, Wieser A, Wulfmeyer V. 2008. Mechanisms initiating deep convection over complex terrain during COPS. Meteorol. Z. 17: 931-948.

Lenschow DH, Stankov BB, Mahrt L. 1979. The rapid morning boundarylaver transition. J. Atmos. Sci. 36: 2108-2124.

Pal S, Behrendt A, Wulfmeyer V. 2010. Elastic-backscatter-lidar-based characterization of the convective boundary layer and investigation of related statistics. Ann. Geophys. 28: 825-847.

Radlach M, Behrendt A, Wulfmeyer V. 2008. Scanning rotational Raman lidar at $355 \mathrm{~nm}$ for the measurement of tropospheric temperature fields. Atmos. Chem. Phys. 8: 159-169.

Richard E, Buzzi A, Zängl G. 2007. Quantitative precipitation forecasting in the Alps: The advances achieved by the Mesoscale Alpine Programme. Q. J. R. Meteorol. Soc. 133: 831-846.

Richard E, Chaboureau J-P, Flamant C, Champollion C, Hagen M, Schmidt K, Kiemle C, Corsmeier U, Barthlott C, Di Girolamo P. 2011. Forecasting summer convection over the Black Forest: a case-study from the Convective and Orographically-induced Precipitation Study (COPS) experiment. Q. J. R. Meteorol. Soc. 137(S1): 101-117, DOI: 10.1002/qj.710. 
Roberts RD, Rutledge S. 2003. Nowcasting storm initiation and growth using GOES-8 and WSR-88D data. Weather and Forecasting 18: $562-584$.

Rotach MW, Ambrosetti P, Ament F, Appenzeller C, Arpagaus M, Bauer H-S, Behrendt A, Bouttier F, Buzzi A, Corazza M, Davolio S, Denhard M, Dorninger M, Fontannaz L, Frick J, Fundel F, Germann U, Gorgas T, Hegg C, Hering A, Keil C, Liniger MA, Marsigli C, McTaggart-Cowan R, Montani A, Mylne K, Ranzi R, Richard E, Rossa A, Santos-Muñoz D, Schär C, Seity Y, Staudinger M, Stoll M, Volkert H, Walser A, Wang Y, Werhahn J, Wulfmeyer V, Zappa M. 2009a. MAP D-PHASE: Real-time demonstration of weather forecast quality in the Alpine region. Bull. Am. Meteorol. Soc. 90: 1321-1336

Rotach MW, Ambrosetti P, Ament F, Appenzeller C, Arpagaus M, Bauer H-S, Behrendt A, Bouttier F, Buzzi A, Corazza M, Davolio S, Denhard M, Dorninger M, Fontannaz L, Frick J, Fundel F, Germann U, Gorgas T, Hegg C, Hering A, Keil C, Liniger MA, Marsigli C, McTaggart-Cowan R, Montani A, Mylne K, Ranzi R, Richard E, Rossa A, Santos-Muñoz D, Schär C, Seity Y, Staudinger M, Stoll M, Volkert H, Walser A, Wang Y, Werhahn J, Wulfmeyer V, Zappa M. 2009b. Supplement: Additional applications of the D-PHASE datasets. Bull. Am. Meteorol. Soc. 90: electronic supplement: S28-S32.

Steinacker R, Häberli C, Pöttschacher W. 2000. A transparent method for the analysis and quality evaluation of irregularly distributed and noisy observational data. Mon. Weather Rev. 128: 2303-2316.

Steinacker R, Ratheiser M, Bica B, Chimani B, Dorninger M, Gepp W, Lotteraner C, Schneider S, Tschannett S. 2006. A mesoscale data analysis and downscaling method over complex terrain. Mon. Weather Rev. 134: 2758-2771.

Schwitalla T, Zängl G, Bauer H-S, Wulfmeyer V. 2008. Systematic errors of QPF in low-mountain regions. Meteorol. Z. 17: 903-919.

Weckwerth TM. 2000. The effect of small-scale moisture variability on thunderstorm initiation. Mon. Weather Rev. 128: 4017-4030.

Weckwerth TM, Parsons DB. 2006. A review of convection initiation and motivation for IHOP_2002. Mon. Weather Rev. 134: 5-22.

Weckwerth TM, Wilson JW, Wakimoto RM. 1996. Thermodynamic variability within the convective boundary layer due to horizontal convective rolls. Mon. Weather Rev. 124: 769-784.

Weckwerth TM, Parsons DB, Koch SE, Moore JA, LeMone MA, Demoz BB, Flamant C, Geerts B, Wang J, Feltz WF. 2004. An overview of the International $\mathrm{H}_{2} \mathrm{O}$ Project (IHOP_2002) and some preliminary highlights. Bull. Am. Meteorol. Soc. 85: 253-277.

Whiteman DN, Demoz B, Di Girolamo P, Comer J, Veselovskii I, Evans K, Wang Z, Sabatino D, Schwemmer G, Gentry B, Lin R-F, Behrendt A, Wulfmeyer V, Browell E, Ferrare R, Ismail S, Wang J. 2006. Raman Water Vapor Lidar Measurements During the
International H2O Project. II. Case Studies. J. Atmos. Oceanic Technol. 23: $170-183$

Wilson JW, Schreiber WE. 1986. Initiation of convective storms at radarobserved boundary-layer convergence lines. Mon. Weather Rev. 114: 2516-2536.

Wulfmeyer V. 1999. Investigation of turbulent processes in the lower troposphere with water vapor DIAL and radar-RASS. J. Atmos. Sci. 56: $1055-1076$.

Wulfmeyer V, Behrendt A (eds) and the COPS Investigators. 2007. 'COPS Field Report.' Available at https://www.unihohenheim.de/cops/further_reading/further_reading.htm.

Wulfmeyer V, Behrendt A, Bauer H-S, Kottmeier C, Corsmeier U, Blyth A, Craig G, Schumann U, Hagen M, Crewell S, Di Girolamo P, Flamant C, Miller M, Montani A, Mobbs SD, Richard E, Rotach MW Arpagaus M, Russchenberg H, Schlüssel P, König M, Gärtner V, Steinacker R, Dorninger M, Turner DD, Weckwerth TM, Hense A, Simmer C. 2008. The Convective and Orographically-induced Precipitation Study: A research and development project of the World Weather Research Program for improving quantitative precipitation forecasting in low-mountain regions. Bull. Am. Meteorol. Soc. 89: $1477-1486$.

Wulfmeyer V, Bösenberg J. 1996. Single-mode operation of an injection-seeded alexandrite ring laser for application in watervapor and temperature differential absorption lidar. Opt. Lett. 21: $1150-1152$.

Wulfmeyer V, Behrendt A, Kottmeier C, Corsmeier U, Barthlott C, Craig GC, Hagen M, Althausen D, Aoshima F, Arpagaus M, Bauer H-S, Bennett L, Blyth A, Brandau C, Champollion C, Crewell S, Dick G, Di Girolamo P, Dorninger M, Dufournet Y, Eigenmann R, Engelmann R, Flamant C, Foken T, Gorgas T, Grzeschik M, Handwerker J, Hauck C, Höller H, Junkermann W, Kalthoff N, Kiemle C, Klink S, König M, Krauss L, Long CN, Madonna F, Mobbs S, Neininger B, Pal S, Peters G, Pigeon G, Richard E, Rotach MW, Russchenberg H, Schwitalla T, Smith V, Steinacker R, Trentmann J, Turner DD, van Baelen J, Vogt S, Volker H, Weckwerth T, Wernli H, Wieser A, Wirth M. 2011. The Convective and Orographically-induced Precipitation Study (COPS): the scientific strategy, the field phase and research highlights. Q. J. R. Meteorol. Soc. 137(S1): 3-30, DOI: 10.1002/qj.752.

Wulfmeyer V, Feingold G. 2000. On the relationship between relative humidity and particle backscattering coefficient in the marine boundary layer determined with differential absorption lidar. J. Geophys. Res. 105: D4, 4729-4741. 